\title{
7. Latinos in Australia
}

\author{
Victor Del Río
}

\section{Introduction}

This chapter takes us into the past, present and future of Latin Americans living in Australia. It represents the first comprehensive quantitative study of the integration of Latinos into their adopted motherland. The only precedent is the study carried out by the Spanish-born Rafaela López in 2002 on the contributions of Spanish and Latin American people in Victoria. ${ }^{1}$

It provides ample evidence that historically Latino communities have been part of the fabric of Australia, albeit in small numbers. It confirms also the communities' struggle to insert themselves into Australian society and their success in achieving it.

It finds that the Latino integration process in the past 40 years operated at two speeds. The first wave of Latino immigrants who arrived before the mid-1990s integrated rather slowly. They had to negotiate a new language and fight for the recognition of their members' work experience and studies obtained abroad. They had to follow an integration path that began in factories performing manual labour and which allowed them to begin climbing the economic and social ladder.

The second Latino migrant wave, which began in 1998, is integrating faster than the first. Language skills and recognition of qualifications are no longer barriers, either because the first wave of Latinos smoothed the path for recognition of overseas qualifications or because the most recent arrivals possessed qualifications gained as international students, most at Australian institutions. Yet these second-wave migrants had to overcome other obstacles. The new and highly qualified Latino communities have to reassert their credentials in the local employment market; they also need to develop social support networks that help to ease their political, economic, and social integration into Australia.

\footnotetext{
1 Rafaela López, Orígenes. Influencia y contribución de origen español y latino Americano en Victoria, 19012001 (The presence and contribution of Victorians of Spanish and Latin American origins, 1901-2001). Australia: CELAS, the Spanish Latin American Welfare Centre, 2002. For short entries on Latin Americans in Australia, also see James Jupp (ed.), The Australian People: An Encyclopedia of the Nation, Its People and Their Origins, Cambridge University Press, Second edition, Cambridge, 2001. For Argentinians, p. 170; Brazilians, p. 187; Chileans, p. 195; Colombians, p. 226; Ecuadorians, p. 273; Peruvians, p. 619; Salvadorians, p. 642; Uruguayans, p. 719; Latin Americans in general, p. 552.
} 


\section{Latino communities: Definitions and categories}

For the purpose of this chapter the concept of Latino includes anyone from the Spanish and Portuguese-speaking peoples from Latin America living in Australia. ${ }^{2}$ Out of this group we selected the ten most significant Latino communities in Australia based on population - as per the 2011 Census - on which to conduct detailed analysis. Both terms - Latino and Latin-American - are used interchangeably, ${ }^{3}$ and they are applicable to both plural and singular usage. Whenever possible, information from the Spanish community is also included. ${ }^{4}$

It is clear from statistical analysis that we have two identifiable categories of Latino communities. The first is formed by Latinos who settled in Australia in the 1970s and the 1980s and migrated mainly under the Special Humanitarian Program and/or Family Reunion Programs from: Argentina, Uruguay, Chile, El Salvador, Guatemala, Honduras and Nicaragua.

The second group arrived in Australia in the 1990s and at the turn of the 21st century and migrated following the opportunities opened by Australia to international students. They largely hail from Brazil, Colombia, Mexico, Venezuela, Peru and Ecuador. Researchers such as Angel Calderón identify the immigration period from 1990 to 2000 as a distinctive wave that was 'dominated by family reunion and waning conflict' ${ }^{5}$

Both groups exhibit distinctive characteristics and contribute differently to Australia. For instance, Uruguayans have participated strongly in Australia's political life and in the employment market. Most of the members of the new migration wave, including from Brazil, Colombia, Venezuela and Mexico, have impressive credentials.

2 Although geography plays an important role, it is not always something that determines the main characteristic of our target group. Language is important, too, as there are several countries in Latin America which have English and French as their official language. For this reason a restricted definition of Latin America is used here: mention of Latin America indicates countries where either Spanish or Portuguese are spoken as the official language. After applying this filter, 20 countries were left in the target research list, excluding the Falkland/Malvinas Islands.

3 In a strict sense 'Latino' is not the perfect term, as in Romance languages it also includes French. But it is a widely accepted concept in the United States and less controversial than others such as Hispano-American, Ibero-American, etc., which have historical connotations linked to the Spanish conquest.

4 As language is one of the core filtering characteristics in this research, people from Spain could not be set aside without losing conceptual consistency. Latin American countries are intrinsically linked to Spain by history, which is therefore an important selective characteristic to take into consideration. Spanish people have also played an important role in the Latin American settlement process in Australia, both politically and academically. For instance, the first political links between Latin American communities and Australia emerged from the Spanish community - see detailed discussion in the section related to political participation. Academically, the first comprehensive analysis of the Spanish-speaking people in Victoria was produced by the Spanish-born Rafaela López.

5 Angel Calderón, 'Latin America tertiary education as an emerging system-Australia's future market', paper delivered at Melbourne-Latin America Dialogue, The University of Melbourne, August 2012. 
This chapter focuses on the first generation of Latinos in Australia, as the information from the 2011 Census is not specific enough to conduct a detailed analysis of the second generation. Future writers may take this gap as an opportunity to research further into the second generation's integration process and its contribution to Australia.

\section{Latino history in Australia}

\section{The first recorded 'Latino' in Australia}

There is both direct and indirect evidence of five Chileans arriving in Australia in 1837. The most prominent of these, Ramón Freire, ${ }^{6}$ played a key role in Chile's history. Freire arrived in Sydney on 3 July 1837, after being ousted from his position as President of Chile and exiled by a military coup. He was also the patriarch of a dynasty of future presidents, with his direct descendant, Eduardo Frei Montalva, assuming the role from 1964-70, and Montalva's eldest son, Eduardo Frei Ruiz-Tagle, reviving the dynasty by becoming president during the term 1994-2000. Ramón Freire's high public status allows us to track his activities during his stay of more than a year in Australia.

Perhaps the most interesting anecdote of Freire's time in Australia was chronicled in The Sydney Herald - where his name was printed as Fryrewhich described him defending the Colony's reputation. This public defence is remarkable because it is the first of its kind to be mentioned in the Hansard of the Legislative Council. The Colonial Secretary had instigated an enquiry to challenge the findings of a Committee of the House of Commons regarding the 'lack of moral standing' of the colony. These allegations 'had created a feeling in the mind of the English public that was prejudicial to the colony' ${ }^{7}$ During a Legislative Council Meeting on 6 July 1838, the Colonial Secretary was recorded as stating that:

he had heard many who came to the colony for the first time say that they were surprised it was so well, and he particularly asked General Fryre, the President of Chili [sic], and he said that before he came here he had no expectations of finding the country in so forward a state, in fact as much safety here as in any country he had visited. If the country was immoral he thought he could turn round to the people of England

Sydney Herald, 'Shipping Intelligence. Arrival', 3 July 1837, p. 2.

7 Sydney Herald, 'Legislative Council', Friday 6 July 1838, pp. 2-3. 
and Ireland who send all their criminals to this colony, and they say they wonder that there were thieves here; who send out thousands of street walkers to this colony... ${ }^{8}$

Freire was not to be the last high-profile Chilean living in Australia. In 1975, Verónica Michelle Bachelet Jeria, daughter of Air Force Brigadier General, Alberto Bachelet Martínez, who opposed the dictator Augusto Pinochet, lived in exile in Sydney for six months. Bachelet was herself destined to become the first woman to secure the presidency of Chile, in 2006. On 7 May 2013 both the Socialist Party and the Party for Democracy in Chile again named Bachelet as their representative in the opposition primaries to obtain their nomination as presidential candidate; Bachelet returned to the presidency in March 2014.

\section{The historical perspective}

According to the 1891 Colonial Census, in the late 1800s there were people from at least 14 Latin American countries living in Australia (see Table 7.1). The same source indicates that there were fewer than 500 people of Latin American extraction living in the Colonies, excluding the state of South Australia, which did not have disaggregated figures. In any case Latin Americans in South Australia could not have reached more than 50 people. This represented just 0.02 per cent of the population of the Australian colonies. Brazil had the highest presence in Australia, representing 31.5 per cent of the Latin American population, followed by Chile (20 per cent), Mexico (ten per cent), and Argentina (eight per cent).

The Latin American arrivals of the 19th century coincided with the gold rush of the 1850s, which supports the view that most Latinos were associated with this massive mining activity. However, the newspapers of the time make it clear that there were other commercial motives. For instance, a relatively high number of advertisements appeared in The Sydney Herald and The Argus (Melbourne) from 1838 to 1916 relating to the Mexican product - 'Mexican Walnut Oil'. The oil was popular in Australia for people who wanted to dye their grey hair. ${ }^{9}$ So while the key attraction may well have been gold, there may have been other commercial magnets accounting for this small but early migration to Australia. 
Table 7.1: Colonial Censuses 1891

\begin{tabular}{|l|r|r|r|r|r|r|}
\hline Country & Victoria & NSW & QLD & WA & Tas & \multicolumn{1}{l|}{ Total } \\
\hline Argentine & 11 & 14 & 6 & 2 & 2 & 35 \\
\hline Brazil & 52 & 45 & 11 & 28 & 2 & 138 \\
\hline Chili & 11 & 53 & 18 & 5 & & 87 \\
\hline Mexico & 10 & 16 & 14 & 5 & & 45 \\
\hline Panama & & & 1 & & & 1 \\
\hline Paraguay & & & 1 & & & 1 \\
\hline Peru & 8 & 11 & 5 & 2 & & 26 \\
\hline Santa Cruz (Bolivia) & & & 1 & & & 1 \\
\hline Hayti or Santo Domingo & 2 & 3 & & & & 5 \\
\hline Nicaragua & 1 & & & & & 1 \\
\hline New Granada & 1 & & & & & 1 \\
\hline Feudador (Ecuador) & 1 & 1 & & & & 2 \\
\hline Uraguay (Uruguay) & 1 & 4 & & 1 & & 6 \\
\hline Colombia & 41 & 56 & 38 & 9 & 3 & 147 \\
\hline South America (no country stated) & 139 & $\mathbf{2 0 4}$ & $\mathbf{9 5}$ & $\mathbf{5 2}$ & $\mathbf{4}$ & $\mathbf{4 3 8}$ \\
\hline Total & & & & & & 1 \\
\hline
\end{tabular}

Note: The South Australia Colonial Census does not have disaggregated figures for America.

Source: HCCD Historical Census and Colonial Data Archives.

\section{The 1970s immigration wave}

Before the 1970s there were so few Latin Americans that the 1961 census did not individually register any community from this region. But significant migration came in the 1970s when policy changes made by Gough Whitlam's Labor government became the engine behind the big Latin American immigration wave which surged from 1973 to the early 90 s.

The following statistical figures give us an idea of the speed and size of this migration movement. It took 25 years (1901-1966) for the Latin American population to quadruple in numbers from a low base of 770 to 3119 people. In contrast, in just five years (1971-1976), there was a growth rate of 215 per cent, when the Latino population grew to 11,335 people. From 1976 to 1981 it once again almost trebled, lifting the population to 32,339. This figure represented 0.29 per cent of the total population in Australia in 1981. This population growth of Latin Americans in Australia has not been seen since. 




Figure 7.1: Latin Americans in Australia from 1891 to December 2012

Source: 3105.0.65.001 Australian Historical Population Statistics, 2008, Released at 11.30am (Canberra time) 5 August 2008.

The 1972 abolition of the White Australia Policy (known as 1901 Immigration Restriction Act) - the main aim of which was to maintain Australia's AngloCeltic culture and ethnic background unchanged - was the first fundamental step towards opening the door to Latin American countries and people from elsewhere. However, it wasn't until 1973 that it really took effect when Minister for Immigration, Al Grassby, delivered the 'Family of the Nation' speech in which he introduced two new terms: 'multiculturalism' and 'social justice', and linked them. The nail in the coffin for the old White Australia policy was the passing of the 1975 Racial Discrimination Act, making any form of racially based selection criteria illegal. A policy of multiculturalism started to flourish across the public policy spectrum. In an historic moment, in 1973, a bipartisan parliament agreed to accept people from Chile as refugees. This bipartisan immigration program for Chile marked:

a break from previous refugee programs that tended to support refugees who were fleeing Communist governments. Between 1974 and 1981, about 6000 Chileans were taken in and (many more) thereafter until the ending of military rule in $1990 .^{10}$

This planned humanitarian program, introduced in 1977 and 1978, replaced the ad-hoc approach that allowed a post-Second World War immigration boom. ${ }^{11}$ Since then, the program's focus has changed each year in response to the global need for resettlement.

10 Barry York, 'Australia and Refugees, 1901-2002: An Annotated Chronology Based on Official Sources', Social Policy Group, Department of Immigration and Ethnic Affairs, Review 1990, Canberra, 1990.

11 Department of Immigration and Citizenship (Economic Analysis Unit, Chief Economist), 'Population 




\section{Figure 7.2: Top four Latin American people in Australia under the Special Humanitarian Program (SHP)}

Sources: Infosheets by country, Museum of Immigration Victoria and the Department of Immigration and Border Protection: Migration and settlement research and statistical information 1966-2012.

As part of this new approach, people from other Latin American countries like Argentina and Uruguay were officially included in the list of those permitted to apply for refugee status.

In 1978, the new categories of skilled migration and family reunion also opened a new avenue to expand the number of Latinos in Australia.

However, not all Latino groups warmly embraced these new immigration opportunities. Australia took only a small number of Cubans (40) as most Cubans leaving Cuba wanted to settle in the US. ${ }^{12}$ In fact the number of Cubans in Australia has remained very small, with only 635 Cubans identified in the Census of 2011.

Malcolm Fraser's Liberal government extended more immigration opportunities to Latin Americans in 1981 and 1982 with a review of its refugee policy. This review resulted 'in the termination of the White Russian program and the extension of the Latin American program ${ }^{\prime 13}$ and, in 1982, to a substantial number of people from El Salvador and, to a lesser extent, other Central America countries (Guatemala, Nicaragua and Honduras) being accepted into Australia under the refugees and Special Humanitarian Program (SHP). ${ }^{14}$

Again reviewing the immigration program in 1983 the Hawke Labor government endorsed the refugee policy but 'diversifie[d] the intake to reflect the global

12 UNHCR, The State of the World's Refugees, 1997-1998, Oxford University Press, 1997, p. 48.

13 Department of Immigration and Ethnic Affairs, Review '81, Canberra, 1981, pp. 6, 56.

14 Department of Immigration and Ethnic Affairs, Review '82, Canberra, 1982, pp. 56, 57. 
dimensions of refugee problems'. ${ }^{15}$ The result was a greater focus on Central and South America than earlier. This move is clearly reflected in the arrivals statistics. In 1985, there was a significant increase in resettlement of people from South and Central America (1717), half of whom were Salvadorans. ${ }^{16}$

An earthquake in Chile in March 1985 prompted Australia to hasten the processing time for family visas from the affected country. The flow of refugees from Latin America remained quite steady for the following two years. In 1985, there was yet another boost when Labor Treasurer, Paul Keating, announced an increase in the Family Reunion Program. ${ }^{17}$

However, the Humanitarian and Special Humanitarian Program (SHP), like any other massive program of this nature, was open to abuse. When I was working for the Spanish Latin American Welfare Centre (CELAS) in 1986, I became aware of a number of people related to the Salvadorian death squads arriving in Australia under the program. In 1986, Rafaela López, the President of CELAS, wrote a letter to the Department of Immigration and Ethnic Affairs complaining about the alleged violations of the spirit of this program. CELAS demanded an enquiry. However the Department did not respond. These abuse allegations were given further weight by the SBS Television program, Vox Populi, which interviewed five alleged Salvadorian victims.

Another direct example of irregularities came from Professor Desmond Cahill who wrote an obituary for Father Bruno Moretti in which he mentioned that '[Father Moretti] also came in contact with a man who claimed he had been the one who had killed Archbishop Oscar Romero in El Salvador in 1980 and came to Australia on false papers'. ${ }^{18}$

Sister Beatry Santos, who researched the Salvadorian community in Australia, also noted that the community was 'paralysed by fear', as the people whom she met and interviewed claimed that very dangerous individuals belonging to the guerrilla and the death squads were living in Australia. She argued that the fragmented Salvadorian community habit of maintaining a low political and social profile in Australia could well be the result of this fear and trauma. I have learnt through unofficial channels that the Department of Immigration and Ethnic Affairs had, indeed, launched an internal investigation. Unfortunately, there are no public records of the investigation's findings.

Another case, this time related to Uruguay, was documented by the $\mathrm{ABC}$ filmmaker, Ian Walker, who investigated the arrival of at least one infamous

15 Department of Immigration and Ethnic Affairs, Review '83, Canberra, 1983, pp. 1, 27, 31.

16 Department of Immigration and Ethnic Affairs, Review '85, Canberra, 1985, pp. 68-9.

17 Ibid., p. 135.

18 The Age, Obituaries 'Priest at home with Melbourne's migrants', 13 January 2005, p. 7. 
Uruguayan torturer to Australia. According to Mr Walker, the torturer's arrival was the product of negotiations between intelligence services: 'The CIA, ASIO and a large American multinational all conspired to have him resettled in Australia' ${ }^{19}$ Notwithstanding these examples the vast majority of people under these programs were legitimate.

The participation rate of Latin Americans in the humanitarian programs (mainly from Chile and El Salvador) remained very strong until 1990, even when other world events looked likely to affect the Latin American intake. On 27 June 1989, the government granted Chinese nationals who were in Australia at the time of the Beijing Tiananmen Square incident temporary residence for four years under a special category of permit. There were about 20,000 people in this category in Australia in 1990. However, in 1991 people from Latin American countries were still representing 20 per cent of the Australian refugee and SHP intake program.

The big shift downward came in 1992, when the Labor Minister for Immigration, Gerry Hand, in announcing the Refugee, Humanitarian and Special Assistance migration categories for the next financial year, indicated that 'numbers admitted under the Central American and Indo-Chinese programs will be smaller than in recent years reflecting declining resettlement needs'. ${ }^{20}$ This marked the beginning of the end of the migration intake under the Humanitarian and Special Humanitarian programs. By 1996 the Latin American migration under the Humanitarian and Special Humanitarian Programs had effectively closed for El Salvadorians. However the government accepted a small number of Colombians (13) in 2001-02, under these programs.

The new Howard Liberal government in 1996 changed the immigration policy as soon as it took power. In October of that year, Minister Ruddock criticised the Opposition for creating a migration program when it was in office that was 'out of balance and rapidly losing public confidence'. ${ }^{21}$ According to the Minister, family migration had grown significantly at the expense of the skilled intake, and he intended to restore the balance. He accordingly increased the Skilled Migration Program (SMP) and decreased the Family Reunion quotas. The new migrant Latin American numbers coming under the Family Reunion Program quickly diminished.

19 ABC Radio National, 'Tortured Questions', Background Briefing, 26 May 1996.

20 Minister for Immigration, Local Government and Ethnic Affairs, Media Release, MPS 41/92, 24 July 1992.

21 Minister for Immigration and Multicultural Affairs, Media Release, MPS27/96, 3 July 1996 and MPS70/96, 30 October 1996. 
Table 7.2: South America, Central America and the Caribbean refugee and SHP programs

\begin{tabular}{|l|r|r|r|r|}
\hline FY & Colombia & El Salvador & Other & Total \\
\hline $91 / 92$ & - & 916 & 36 & 952 \\
\hline $92 / 93$ & - & 288 & 9 & 297 \\
\hline $93 / 94$ & - & 132 & 17 & 149 \\
\hline $94 / 95$ & - & 154 & 24 & 178 \\
\hline $95 / 96$ & - & 137 & 41 & 178 \\
\hline $96 / 97$ & - & 77 & - & 77 \\
\hline $97 / 98$ & - & 49 & 1 & 50 \\
\hline $98 / 99$ & - & 7 & 17 & 24 \\
\hline $99 / 00$ & - & 9 & 10 & 19 \\
\hline $00 / 01$ & - & 5 & 9 & 14 \\
\hline $01 / 02$ & 13 & - & 13 & 26 \\
\hline
\end{tabular}

Source: Infosheets by Country, Museum of Immigration Victoria and the Department of Immigration and Border Protection: http://www.immi.gov.au/media/fact-sheets/\#stats.

For instance, in 2002-03, 64 per cent of Latin Americans migrated to Australia under the Family Reunion category and 27 per cent did so under the SMP. By 2008-09 the Family Reunion Program representation had fallen to 44 per cent and the skilled migration representation had increased to 53 per cent. In particular, people migrated under the newly created category of Independent Migration using the Visa Sub-class 885 and Visa Sub-class 886. These two visas were created by the Howard government to attract international students living in Australia who had obtained an Australian certificate as a result of at least two years of study. From 2002-03 to 2010-11 the number of Latin Americans settling in Australia every year under the Independent category grew by 300 per cent, from 249 to 1013 people. These visas became the means by which many Latin American immigrants have been able to settle permanently in Australia. In particular, these visas benefited Latinos from Brazil, Colombia and Venezuela, and swelled the numbers in Australian Latino communities by 40 per cent from 2009 to December 2012.

\section{The Latin American population in $\mathbf{2 0 1 2}$}

In December 2012, there was a Latin American first generation population of 105,886 people - this figure excludes Spain - living as residents or citizens in Australia. 
This represented 0.49 per cent of the total population of Australia $(21,507,715)$ substantial compared to the 0.04 per cent registered in $1891 .{ }^{22}$

According to the 2011 Census, the ten largest national groupings of Latin American peoples in order of population size in Australia are those from: Chile, Brazil, Argentina, Colombia, Uruguay, El Salvador, Peru, Venezuela, Mexico and Ecuador. The Department of Immigration figures from 2011 to December 2012 indicate that Colombia and Argentina have already shifted places.

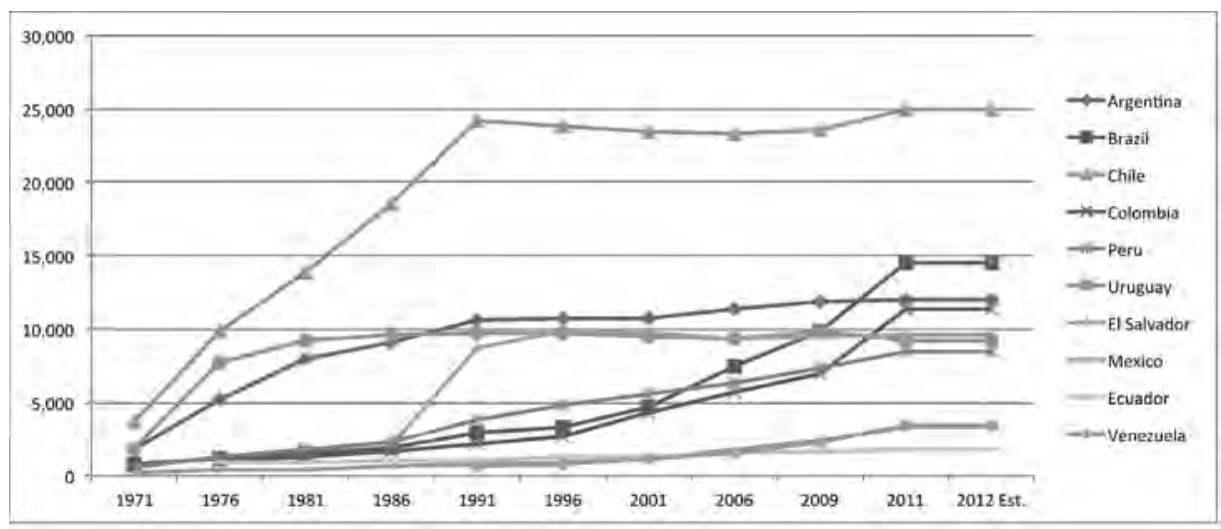

Figure 7.3: Top ten Latin Americans in Australia by country of origin from 1971 to December 2012

Source: ABS Census 2011 plus the Department of Immigration net additions from 2011 to December 2012.

\section{Latino age profile}

The age profile of the Latino Community confirms the demographic differences between old and new Latino settlers.

Uruguayans have an older population, with 42 per cent at 60 years of age and over, and only two per cent under the age of 19. Conversely, Venezuela has 13 per cent under 19 years of age and only three per cent who are 60 years of age and over. Brazilians comprise an overwhelmingly young community, with 76 per cent under 39 years of age, compared with 54 per cent for the entire Australian population.

22 These figures are based on the 2011 Census as well as on Department of Immigration and Citizenship statistical information concerning new permanent arrivals and departures (net additions) and do not discount people who died from 1 July 2011 to 30 December 2012, as this information was not available by country of birth. 
It is interesting to note that although we classify Ecuador as a member of the new immigration wave, its community is relatively older than the others, as 25 per cent of its members are 60 years of age and over. This represents five per cent more than the Australian average of 20 per cent.

The new Latino communities' relatively youthful age profile indicates that the best contribution they can make to Australian society is yet to occur.

Table 7.3: Latin American people by country of origin and age group

\begin{tabular}{|l|r|r|r|r|}
\hline Age & $\mathbf{0 - 1 9}$ years & $\mathbf{2 0 - 3 9}$ years & $\mathbf{4 0 - 4 9}$ years & $\mathbf{6 0}$ years and over \\
\hline Australia & $\mathbf{2 6 \%}$ & $\mathbf{2 8} \%$ & $\mathbf{2 7} \%$ & $\mathbf{2 0} \%$ \\
\hline Argentina & $5 \%$ & $29 \%$ & $39 \%$ & $\mathbf{2 7} \%$ \\
\hline Brazil & $8 \%$ & $68 \%$ & $20 \%$ & $5 \%$ \\
\hline Chile & $4 \%$ & $27 \%$ & $40 \%$ & $28 \%$ \\
\hline Colombia & $9 \%$ & $64 \%$ & $21 \%$ & $6 \%$ \\
\hline Ecuador & $8 \%$ & $32 \%$ & $35 \%$ & $25 \%$ \\
\hline El Salvador & $3 \%$ & $44 \%$ & $39 \%$ & $15 \%$ \\
\hline Mexico & $12 \%$ & $61 \%$ & $20 \%$ & $6 \%$ \\
\hline Peru & $7 \%$ & $42 \%$ & $35 \%$ & $16 \%$ \\
\hline Uruguay & $2 \%$ & $15 \%$ & $42 \%$ & $42 \%$ \\
\hline Venezuela & $13 \%$ & $57 \%$ & $27 \%$ & $3 \%$ \\
\hline Spain & $5 \%$ & $17 \%$ & $35 \%$ & $43 \%$ \\
\hline
\end{tabular}

Source: ABS Census 2011, ABS. Information extracted by the author using Table Builder Basic \& Pro, 8-21 May 2013.

\section{The future-migration trends}

The composition of the community has changed dramatically in the last ten years and will continue to do so. Current migration trends will be affected by changes in the skilled and business migration visas, which have been taking place since 2009. These changes and their impact on migration have yet to be fully measured, but if we consider the intake from 2009 onwards, Brazilians, Colombians, Mexicans and Venezuelans have benefited most.

On current trends, first generation Brazilians will occupy the top rung in the Latino ladder in Australia by 2015. Brazil was number four in skilled migration sourced from the student population in Australia, and fifth in business migration, according to the Department of Immigration's 2011-12 immigration ranking by country (highest-ranking source countries for different types of visas). Colombia was second.

In the same period Colombia occupied the 14th place of all countries from where immigrants came to settle in Australia, sourced from the international student 
population. Among the Latin American sources, Colombia has already taken the third place from Argentina and may overtake Chile by 2020, leaving the Chileans ranked third. Venezuela and Peru follow very closely.

The ranks of Latin American communities will also be increased annually by a floating population of students, temporary workers, and family visits. These new permanent and temporary Latin American communities will shape the attitudes, political and cultural manifestations of the whole Latino community in Australia in a rather different way than in earlier generations. It is expected that the new migration wave will exploit its qualifications and English proficiency to enhance the commercial and economic relationship between Australia and Latin America. We have seen signs of these changes with the opening of new highquality Mexican and Argentinean restaurants in Australia since 2010 owned by first generation Mexicans and Argentineans.

Family migration and particularly people who came to study in Australia for postgraduate degrees are filling the void left by the exclusion of Latin American countries from Australian refugee and special humanitarian programs. This new Latin American wave will make its own mark on the future history of Australia.

\section{Integrating into the new motherland}

The goal for governments is that migrants adjust rapidly to their adopted country. The OECD highlights the importance of this process:

...the active participation of immigrants and their children in the labour market and, more generally, in public life is vital for ensuring social cohesion in the host country and migrants' ability to function as autonomous and productive citizens, and also for facilitating the acceptance of immigrants by the host-country population. ${ }^{23}$

The OECD Indicators of Immigrant Integration 2012 Report defines and benchmarks a number of indicators to measure the outcomes for immigrants and their children. The 2011 Census allowed us to extract the relevant information to produce and compare, whenever possible, the immigrant outcomes in Australia with the indicators contained in the OECD Report and the pertinent Australian average rate.

This following section analyses civic engagement - represented by citizenship, political participation $^{24}$ and volunteer participation indicators - economic participationlabour force representation, unemployment, levels of income, occupation, and

23 OECD (Organisation for Economic Co-operation and Development), Settling In: OECD Indicators of Immigrant Integration 2012 Report, p. 5.

24 Karina Anthony, 'The Political Representation of Ethnic and Racial Minorities', Briefing Paper 3/06, NSW Parliamentary Library Research Service, 2006. 
employment by industry indicators - education participation-levels of education and English proficiency indicators - and social participation-need of assistance indicator - in order to measure and judge the level of Latino integration in Australia.

Future studies may analyse other indicators and up-to-date information that would improve our current picture of the quality of the settlement process for Latin American people in Australia: this would permit more accurate international comparisons.

\section{Civic engagement: Rates of citizenship}

The OECD states that civic engagement or 'taking an active part in society' is probably one of the best indicators of integration. It demonstrates the extent to which an immigrant has settled in a community and broadened involvement beyond material necessity. ${ }^{25}$ The OECD also notes that a reliable indicator of civic engagement is the rate of citizenship. The report 'Settlement Outcomes of New Arrivals' concurs with this, saying that 'the obtaining or intention to obtain citizenship can be an indicator of connectedness for new migrants' ${ }^{26}$

Invalidation of citizenship of the applicants' country of origin is regarded as increasing the commitment of migrants to a new country. Citizenship of the new country is also regarded as a particularly accurate indicator of community and national commitment because of the stringent legal requisites enforced by the host country that the new migrants are required to overcome. In the case of Australia, the Citizenship Act 2007 calls for a minimum of four years of residency including a period of 12 months as a permanent resident immediately before making an application, and a limited number of absences from Australia of no more than 12 months in total in the four years prior to application, with not more than 90 days in the 12 months immediately prior to application.

The 2011 Census shows adjusted citizenship figures by reducing the number of people who arrived after 2009 and who, for statutory requirements, were ineligible to apply for citizenship - this re-calculated rate is also known an 'adjusted naturalisation rate'. Based on this indicator we can determine that both the old and new Latino communities are well integrated into Australian society compared with the national average of 85 per cent adoption of citizenship for all migrant communities in Australia.

Moreover, the citizenship figures for Latino communities in Australia are far above the latest OECD figures from 2005-06, in which the average citizenship rate for migrant communities was 48 per cent.

25 OECD, Settling In, op. cit., note 23, p. 133.

26 Department of Immigration and Citizenship, Settlement Outcomes of New Arrivals: Report of Findings, Policy Innovation, Research and Evaluation Unit, Department of Immigration and Citizenship, April 2011. 
The Salvadorian communities have a citizenship rate of almost 98 per cent, 13 per cent above the national average. The Argentineans and Uruguayan communities are just above the national average with 88 per cent, while Chile has almost 84 per cent. In the case of Venezuela, dual citizenship is recognised for people of less than 25 years of age only. Despite this barrier, an impressive 88 per cent of Venezuelans acquired Australian citizenship. The rest of the new Latino communities possess consistent citizenship rates, with their time living in Australia just below or above the national average of 85 per cent.

Table 7.4: Latin American people by country of birth and citizenship

\begin{tabular}{|l|r|r|r|r|r|r|r|}
\hline & \multicolumn{6}{|c|}{ Adjusted naturalisation rate 15 years and over } \\
\hline & & & \multicolumn{1}{l}{$\begin{array}{l}\text { Not } \\
\text { Country of } \\
\text { birth }\end{array}$} & Australian & \multicolumn{1}{l}{$\begin{array}{l}\text { Not } \\
\text { Australian } \\
\text { yet } \\
\text { Australian/ } \\
\text { eligible } \\
\text { Australian } \\
\text { plus } \\
\text { eligible } \\
\text { residents }\end{array}$} & $\begin{array}{l}\text { over } \\
\text { eligible } \\
\text { residents }\end{array}$ & Ranking \\
\hline Australia & & & & & & $85 \%$ & \\
\hline Argentina & 9,906 & 1,577 & 236 & 1,341 & 11,247 & $88.1 \%$ & 3 \\
\hline Brazil & 4,724 & 8,832 & 5,734 & 3,098 & 7,822 & $60.4 \%$ & 10 \\
\hline Chile & 18,883 & 5,144 & 1,449 & 3,695 & 22,578 & $83.6 \%$ & 4 \\
\hline Colombia & 4,424 & 6,167 & 5,203 & 964 & 5,388 & $82.1 \%$ & 8 \\
\hline Ecuador & 1,263 & 378 & 158 & 220 & 1,483 & $85.2 \%$ & 5 \\
\hline $\begin{array}{l}\text { El } \\
\text { Salvador }\end{array}$ & 8,972 & 435 & 234 & 201 & 9,173 & $97.8 \%$ & 1 \\
\hline Mexico & 1,192 & 1,722 & 1,139 & 583 & 1,775 & $67.2 \%$ & 9 \\
\hline Peru & 5,560 & 2,380 & 1,460 & 920 & 6,480 & $85.8 \%$ & 6 \\
\hline Uruguay & 8,483 & 536 & 631 & 1,167 & 9,650 & $87.9 \%$ & 2 \\
\hline Venezuela & 1,371 & 1,659 & 1,469 & 190 & 1,561 & $87.8 \%$ & 7 \\
\hline Total & 64,778 & 28,830 & 17,713 & 12,379 & 77,157 & $84.0 \%$ & \\
\hline
\end{tabular}

Note: The figure of not eligible yet was estimated as we did not have the information by age.

Sources: ABS Census 2011, ABS Information extracted by the author using Table Builder Basic \& Pro, 8-21 May 2013.

Although the Brazilian and Mexican communities are part of the new arrivals category, both exhibit low citizenship rates of 60 and 67 per cent respectively, even though there are no barriers to dual nationality. Since 9 June 1994, dual citizenship has been allowed under Brazilian law. In Mexico dual nationality has been recognised since $1998 .{ }^{27}$ The low citizenship rate of both countries must therefore be caused by other unknown factors. In relation to the OECD average

27 Nationality Act, ('New Law published in the Official Journal of the Federation on January 23, 1998'), Ley de Nacionalidad Cámara de Diputados del H. Congreso de la Unión, Secretaría General, Secretaría de Servicios Parlamentarios, Dirección General de Bibliotecas, 20 March 1998. 
of 48 per cent citizenship rate, the Brazilian and Mexican communities have nonetheless performed well. It is clear that neither loss of country-of-origin citizenship nor the arduous requirements to obtain Australian citizenship are significant deterrents to the strong drive for both the old and new waves of Latino migrants to integrate into Australian society.

With an overall citizenship average of 82 per cent, Latino communities now regard Australia as their home, and arguably have developed a sense of connectedness and permanency with the rest of the community.

\section{Civic engagement: Volunteer work}

The 2012 OECD Report, Settling In, includes volunteer work as another important indicator of civic engagement:

Dimensions to gauge the extent to which migrants feel involved in society include involvement in broad voluntary societal activities, which might include membership and participation in associations, volunteer work, and, if by choice, enrolment in trade unions or political parties. Political participation is one dimension of implication in society. ${ }^{28}$

The World Giving Index 2011, ${ }^{29}$ which includes volunteer work, rated Latin American countries well down in rankings for philanthropic contributions. Australia is number three in the ranking and the closest Latin American country is Chile, at 43. The Australian figures from the 2011 Census indicate that all the Latino communities except Mexico rate below the national average of 19 per cent in volunteer work. The Venezuelan community follows with 16 per cent.

Given that Mexicans have one of the lowest rates of citizenship but the highest rate of volunteer work, there is a contradiction between the first civic engagement indicator - the rate of citizenship - and the second - volunteer work. This contradiction warrants further study.

According to the Census 2011, Uruguay possessed the lowest volunteer work rate, with 11 per cent. In the Giving Index Uruguay rated 124th. Colombia, Ecuador and Peru were close on Uruguay's heels with 12 per cent.

There is some evidence to suggest that the low participation of some Latino populations may be explained by cultural factors. According to sources such as the Giving Index, it is uncommon by international standards for Latinos to volunteer in their countries of origin.

28 OECD, Settling In, op. cit., note 23, p. 133.

29 Charities Aid Foundation (CAF), World Giving Index 2011: A Global View of Giving Trends, pp. 44-5. 
Table 7.5: Latin American people by country of birth and volunteer work

\begin{tabular}{|l|r|r|r|r|}
\hline & Not a Volunteer & Volunteer & \multicolumn{1}{l|}{ Total } & \% \\
\hline Australia & $12,851,394$ & $3,090,876$ & $15,942,270$ & $19 \%$ \\
\hline Argentina & 9,528 & 1,615 & 11,143 & $14 \%$ \\
\hline Brazil & 11,448 & 1,951 & 13,399 & $15 \%$ \\
\hline Chile & 20,452 & 2,760 & 23,212 & $12 \%$ \\
\hline Colombia & 9,228 & 1,225 & 10,453 & $12 \%$ \\
\hline Ecuador & 1,385 & 206 & 1,591 & $13 \%$ \\
\hline Peru & 6,766 & 966 & 7,732 & $12 \%$ \\
\hline Uruguay & 7,641 & 954 & 8,595 & $11 \%$ \\
\hline Venezuela & 2,512 & 495 & 3,007 & $16 \%$ \\
\hline El Salvador & 7,923 & 1,176 & 9,099 & $13 \%$ \\
\hline Mexico & 2,330 & 557 & 2,887 & $19 \%$ \\
\hline Total & 79,213 & 11,905 & 91,118 & $13 \%$ \\
\hline Spain & 10,482 & 1,301 & 11,783 & $11 \%$ \\
\hline
\end{tabular}

Note: The figure of not eligible yet was estimated as we did not have the information by age.

Sources: ABS Census 2011, ABS Information extracted by the author using Table Builder Basic \& Pro, from the 8 th to the 21st of May 2013.

\section{Civic engagement: Political participation}

The OECD points to the inclusion of participation in voting in political elections, union and political party memberships and participation in the political system as indicators of integration. For instance, the OECD Report concluded that: 'In most countries, immigrants report a lower participation rate in the most recent election than their native-born counterparts' ${ }^{30}$

This indicator could not be analysed with the same level of statistical detail as others, since the relevant information is not available. In order to evaluate this indicator, relevant studies such as ethnic participation in Australian parliaments was analysed and qualitative information obtained through faceto-face interviews with community leaders who have played critical political and advocacy roles: these included Australia's first Latino MP Telmo Languiller; political adviser Cesar Piperno; activist Angel Calderón; ACTU executive Jorge Nava; electoral advisor Carlos Baldovino; Labor Party candidate Eric Dale; and researchers Beatriz Santos and Rafaela López. 


\section{Successful migrant political participation}

In Australia there is strong evidence of success in first and second generations of Greek and Italian communities in voting popular representatives into the federal and state parliaments and local union movements. The Greek community produced Federal MPs Maria Vamvakinou, Steve Georganas, Petro Georgiou, and Victorian MPs Theo Theophanous, John Pandazopoulos and Nick Kotsiras, among others. From an Italian background were NSW MP Franca Arena (1981-99), Governor of Victoria James Gobbo, and the Member for Makin (SA) Tony Zappia.

However, Latin American political representation has been non-existent at the federal level and very slight, at best, at the state and local council and political party and trade union levels. Victoria has had by far the most Latin American political representation of any state or territory; it is the only state with a member of parliament with Latin American ancestry, Telmo Languiller (Uruguayan), elected in 1999. There have been other popularly elected Latinos, for instance Andrés Puig (Uruguayan), who was Major of the Brimbank Council in 2002; Jenny Barbosa (Uruguayan), who was a former Council member for Brimbank; and Cesar Piperno (Uruguayan), President of the Multicultural Affairs and Population Policy Committee of the Labor Party. South Australia follows with Jorge Navas (Colombian), who has been the Secretary for the Health Services Union since 1987. Navas became a member of the executive committee of the ACTU. At the Federal level a further two Uruguayans have held positions of influence: Carlos Baldovino was the electoral officer of the former Prime Minister Julia Gillard, ${ }^{31}$ and the deceased Fernando Moya worked in the electorate of Holt for Anthony Byrnes, former Parliamentary Secretary for Trade and Parliamentary Secretary to the Prime Minister.

Carlos Baldovino arrived in Australia in December 1977 as a political refugee. Uruguay gave Carlos a painful introduction to life within a dictatorship. In his country of origin he was captured, imprisoned and tortured for five months by the military regime. Carlos joined the Labor Party in 1993. He was raised in a politically charged environment by his father Elvio Baldovino, who maintained a strong commitment to the Labor Party. From 1993 Carlos occupied several administrative positions in the Labor Party, including state and national conference delegate and member of the public office selection committee. He tried to win an Upper House seat in Victoria, failing by just .098 per cent, 1,402 votes short of the 140,000 required to succeed..$^{32}$ Carlos became an electoral officer for Julia Gillard when she was elected to Federal Parliament in 1998.

31 Carlos Baldovino, interview, 9 December 2010

32 Victorian Electoral Commission, 'State Election 1999: Eumemmerring Province'. 
Eric Dale was born in Chile in 1947, and arrived in Australia in 1964. In 1975 he joined the Labor Party as a member of the Ferntree Gully branch. Dale was motivated to join the party by his outrage at the dismissal of the Whitlam government. He has occupied a number of Labor administrative positions, from branch secretary to branch treasurer. Dale co-ordinated the Eastern Suburbs campaign of the Victorian Labor Party that resulted in the electoral victory of the Cain government in 1982. In 1985 and 1988 Dale was himself the ALP candidate for Burwood. He endured an uphill electoral battle and came close to winning the seat held by Jeff Kennett, the Leader of the Liberal Party, since 1976. In 1985 Dale was 1,500 votes short of winning the seat and changing the political history of Victoria. From 1982 to 1989 he worked as adviser to Jim Simmonds, Minister of Employment and Training and later Minister of Local Government. From 1989 to 1992 Dale worked as electoral officer for George Crawford, member for Jika-Jika. He performed the same role for Jean McLean, member for Melbourne West from 1992 to 1996. From 1999 to 2001 Dale worked for Andrew Theophanous as chief of staff. Dale ceased being active within the Labor Party after 2001.

In 1999 Rubén Alex Sánchez tried unsuccessfully to win the seat of Camden in NSW for Labor, losing to Liberal Liz Kernohan. ${ }^{33}$ Mario John Fonseca ran for a seat in the NSW parliament in 2003, representing the Green Party, but secured only 5.6 per cent of the votes. ${ }^{34}$

\section{Why Victoria?}

Most members of the ten largest Latin communities in Australia live in NSW, with their second choice of residence being Victoria - except Brazilians, whose second preference is Queensland; and the community from El Salvador, which prefers Victoria, with Queensland as the second choice. So it may appear unusual that much of the political engagement by the Latino population in Australia has been in Victoria.

In 2005 more than 20 per cent ${ }^{35}$ of Victorian parliamentarians were either born overseas or had parents who were. NSW followed with 14 per cent: migrant representation in the Victorian parliament has been very strong, with greater successful political involvement of the Latin American community in Victoria than in any other state in Australia. The total representation of ethnic parliamentarians at the national level was only 12 per cent. This percentage was, however, a significant improvement on the seven per cent reported for nonEnglish speaking countries by the Department of Immigration and Citizenship

33 New South Wales Election Results 1856-2007 (as at 5 July 2007), 'NSW Elections: Camden - 1999'.

34 New South Wales Election Results 1856-2007 (as at 5 July 2007), 'NSW Elections: Smithfield - 2003'.

35 Anthony, Karina, 'The Political Representation of Ethnic and Racial Minorities', 2006. 
in $1989 .{ }^{36}$ Before September 1999 not one parliamentarian was Latino. The Uruguayan-born Telmo Languiller changed this by winning the lower house seat of Sunshine in Victoria - currently Derrimut - in 1999.

Table 7.6: Latin Americans place of residency

\begin{tabular}{|l|l|l|l|}
\hline Country & $\begin{array}{l}\text { First settling's } \\
\text { choice }\end{array}$ & $\begin{array}{l}\text { Second settling's } \\
\text { choice }\end{array}$ & $\begin{array}{l}\text { Third settling's } \\
\text { choice }\end{array}$ \\
\hline Argentina & NSW & Vic & Qld \\
\hline Brazil & NSW & Old & Vic \\
\hline Chile & NSW & Vic & Old \\
\hline Colombia & NSW & Vic & Old \\
\hline El Salvador & Vic & Old & NSW \\
\hline Peru & NSW & Vic & Old \\
\hline Uruguay & NSW & Vic & Old \\
\hline Mexico & NSW & Vic & Old \\
\hline Venezuela & NSW & Vic & Old \\
\hline Ecuador & NSW & Old & Vic \\
\hline Spain & NSW & Vic & Old \\
\hline
\end{tabular}

Source: ABS Census 2011, ABS. Information extracted by the author using Table Builder Basic \& Pro, 8-21 May 2013.

Table 7.7 Ethnic membership in Australian parliaments in 2005

\begin{tabular}{|l|l|l|l|l|l|l|l|l|l|l|}
\hline $\begin{array}{l}\text { State/ } \\
\text { Territory }\end{array}$ & Cth & NSW & Vic & SA & Qld & WA & NT & ACT & Tas & Total \\
\hline $\begin{array}{l}\text { Total } \\
\text { house } \\
\text { members }\end{array}$ & 226 & 135 & 132 & 69 & 89 & 91 & 25 & 17 & 40 & 824 \\
\hline $\begin{array}{l}\text { Total } \\
\text { ethnic } \\
\text { minority } \\
\text { members }\end{array}$ & $10.6 \%$ & $14.0 \%$ & $20.0 \%$ & $11.0 \%$ & $5.6 \%$ & $8.8 \%$ & $12.0 \%$ & $17.6 \%$ & $5.0 \%$ & $12.0 \%$ \\
\hline
\end{tabular}

Source: Karina Anthony, (2006) The Political Representation of Ethnic and Racial Minorities, Briefing Paper 3/06, NSW Parliamentary Library Research Service.

Overall the total ethnic representation in parliaments was well below the 30 per cent of people who were born overseas or had parents who were not born in Australia.

36 Department of Immigration and Citizenship, National Agenda for a Multicultural Australia, http://www. immi.gov.au/media/publications/multicultural/agenda/agenda89/issues.html. 
Table 7.8: Ethnic members by party 2005

\begin{tabular}{|l|l|l|l|l|l|l|l|l|l|l|}
\hline $\begin{array}{l}\text { State/ } \\
\text { Territory }\end{array}$ & Cth & NSW & Vic & SA & Qld & WA & NT & ACT & Tas & Total \\
\hline $\begin{array}{l}\text { Total ethnic } \\
\text { members by } \\
\text { party }\end{array}$ & 24 & 19 & 27 & 8 & 5 & 8 & 3 & 3 & 2 & 99 \\
\hline $\begin{array}{l}\text { ALP / Territory } \\
\text { Labor }\end{array}$ & $38 \%$ & $74 \%$ & $85 \%$ & $63 \%$ & $89 \%$ & $75 \%$ & $67 \%$ & $33 \%$ & $50 \%$ & $66 \%$ \\
\hline Democrats & $4 \%$ & $0 \%$ & $0 \%$ & $0 \%$ & $0 \%$ & $0 \%$ & $0 \%$ & $0 \%$ & $0 \%$ & $1 \%$ \\
\hline National Party & $4 \%$ & $16 \%$ & $0 \%$ & $0 \%$ & $0 \%$ & $0 \%$ & $0 \%$ & $0 \%$ & $0 \%$ & $4 \%$ \\
\hline $\begin{array}{l}\text { Country } \\
\text { (Liberal) Party }\end{array}$ & $54 \%$ & $5 \%$ & $15 \%$ & $25 \%$ & $20 \%$ & $25 \%$ & $33 \%$ & $67 \%$ & $50 \%$ & $27 \%$ \\
\hline $\begin{array}{l}\text { Independent / } \\
\text { Minor Party }\end{array}$ & $0 \%$ & $5 \%$ & $0 \%$ & $13 \%$ & $0 \%$ & $0 \%$ & $0 \%$ & $0 \%$ & $0 \%$ & $2 \%$ \\
\hline
\end{tabular}

Source: Karina Anthony, (2006) The Political Representation of Ethnic and Racial Minorities, Briefing Paper 3/06, NSW Parliamentary Library Research Service.

\section{The role of the established migrant communities (Spanish and Greek)}

The Spanish and Greek communities played a central role in advancing the Latin American political resettlement process within the Australian system. As the oldest Spanish-speaking community in Australia, Spaniards had settled well before the arrival of Latin Americans in the 1970s. Spaniards migrated all over the world after 1940 to escape the dictatorship of General Franco. During the 1970s they had already established links with the union movement in Australia. For instance, they initiated the workers' commissions (comisiones obreras) in conjunction with the Greek community and with links to the unions. ${ }^{37}$ Both the Spanish and Greek communities shared a similar ideology and held common interests and enemies, as each had first-hand experience of the horrors of dictatorships. This common heritage encouraged a loose alliance between the Spanish and Greek communities.

The Latin Americans' lack of English skills and political and union contacts in Australia was compensated for by a strong will to advance the human rights and democratisation agendas in their own motherlands. The Spaniards and the Greeks were sympathetic to this cause and were more than willing to provide logistical support to the new Latin Americans. This support allowed them to organise and to form resistance groups in exile against dictatorships in Latin America. For instance, the Spanish community frequently lent the Spanish Club 
located in Gertrude St, Fitzroy, to the new politically active groups. The Greek community did the same by lending its premises, the 'Democrat's Building' in Nicholson St, Fitzroy. ${ }^{38}$ The alliance between Spaniards and new Latin Americans grew stronger throughout the years, due to mutual recognition of their common experience of political persecution in their home countries.

\section{The unions' role}

The new Latin Americans were also supported by the trade union movement in Australia, which sympathised with the human rights and democratisation agendas of the politically active new migrants. This support took the form of providing access to venues for meetings and to office equipment, interpreting, and printing facilities.

Incrementally the Australian union movement also became aware of the importance of attracting new arrivals to their ranks. A number of unions gathered to establish a working commission to achieve this goal. Among these were the Metalworkers' Union, the Meat Workers' Union, the Textile and Clothing Union, the Miscellaneous Union, the Liquor Trade Union, and the Health Services Union. The commission established the Trade Union Migrant Workers' Centre (TUMWC) in $1976^{39}$ and employed María Pozos, a Spaniard, to serve as a conduit with the Spanish-speaking groups and to facilitate the new arrivals' integration into the Australian union movement. ${ }^{40}$ María filled a crucial role which sought to redress the lack of English-language skills characteristic of new arrivals. Telmo Languiller commented: 'I had a number of meetings with her and these encounters were crucial to opening my eyes and to establishing solid relationships with the union movement' ${ }^{41}$ Joe Caputo, one of the people who established the TUMWC, explained the role of this organisation during an interview in February 2009:

\footnotetext{
38 Ibid.

39 The Trade Union Migrant Workers' Centre (TUMWC) was established in 1976 by a small group of unions as a result of a proposal during the second Migrant Workers' Conference in 1975. The Centre's primary aim was to strengthen the links between non-English speaking workers and their unions. Membership of the TUMWC was open to any Victorian union affiliated with the Victorian Trades Hall Council. It was funded by unions that recognised and understood the needs and problems of migrant workers, and by various state and federal government funding programs during its existence. The Centre was based at the Metal Trades Union, East Melbourne, until the TUMWC's move in the late 1980s to the Trades Hall building. The Centre's role included assisting injured workers with Workers' Compensation matters, translation and interpreting, case work and counselling. By the late 1980s the Centre had lost a component of its government funding and affiliation fees from trade unions were insufficient to maintain its previous staffing levels and programs. Despite attempts to provide a more secure financial base through the establishment of a Migrant Workers' Bureau at Trades Hall, the TUMWC closed on 23 July 1991, having insufficient funds to continue. See: Victorian Trades Hall Council. Archives at the University of Melbourne 101/27, 1976-91, 13 Arki Boxes http://www.lib.unimelb.edu.au/ collections/archives/collections/.

40 Rafaela López, interview, 14 May 2010.

41 Telmo Languiller, interview, op. cit., note 37
} 
...90 per cent of it was used for translating, interpreting for union officials; translating documents for union journals and the like. But even that was a step forward, at least there was recognition that you had people from different backgrounds and they needed to be-you know, you needed to communicate to those people in their languages. ${ }^{42}$

According to Languiller, the creation of the TUMWC was in recognition of the need 'to respond to non-English speaking workers' needs. ${ }^{\prime 3}$ Languiller remembers a number of conversations with Jim Ralston, Metal Workers' Union Secretary about the ways in which to do this. Languiller's informal links with the Union developed into a formal relationship when the TUMWC organiser, Jim O'Neill, recommended him to John Halfpenny, Victorian Secretary of the Amalgamated Metal Workers' Union, to fill a new organiser position within the TUMWC. Languiller's journey with the union movement lasted 14 years; seven years with the TUMWC and another seven with the Health Services Union. Other Latin Americans have followed this route, such as the Chilean Tony Medina, former CFMEU organiser and Victorian asbestos campaigner who died in 2008 of asbestosis at the age of 43-Medina worked with the well-known union campaigner, Bernie Banton; ${ }^{44}$ and Colombian Jorge Navas, Secretary of the Health Services Union in South Australia since 1987.

The story of Jorge Navas is not dissimilar to that of Telmo Languiller. A chance encounter with Don Dunstan, then Premier of South Australia, opened the possibility for Jorge to remain in the country after a difficult separation from his Australian partner. Once his immigration status was resolved, Jorge began working for the Health Services Union as a cleaner, kitchen-hand and operations theatre technician. For many years after his arrival Jorge did not develop political relationships with the Australian Latin American community as he was committed first to obtaining proficiency in the English language: he regarded a close relationship with other Latin Americans as unhelpful in achieving this goal. Jorge was proactive in enrolling new members to a union which in the late 1980s was very weak. His efforts were recognised by a union secretary in 1987, who asked him to adopt this role. As a member of the union he actively participated in supporting Nicaraguan and Colombian solidarity groups and victims of HIV/AIDS. He has remained close to the human rights agenda linked to Colombia.

\footnotetext{
42 Migrant Workers' Centres in multiculturalism. Joe Caputo locates the key role of Migrant Workers' Centres in the development of multiculturalism. Created: unknown. Date Added: 18 February 2009. Source: not available. Format: mov (Quicktime); File size: 14.9 MB. Length: 05min 43sec.

43 Telmo Languiller, interview, op. cit., note 37.

44 See Bernie Banton Foundation, http://www.berniebanton.com.au/, accessed 2 November 2013.
} 


\section{The path from union engagement to the Labor Party}

The Labor Party also supported the human rights and democratisation agendas of new migrants, in particular those from Latin America. This support took the form of providing access to solidarity groups, office equipment, communications, printing facilities, and access to venues.

The arrival of Elvio Baldovino was a political landmark within the Latin American community. Baldovino had been a ports union leader in Uruguay. He fled Uruguay when union officials warned that the army was searching for him. In the late 1970s he organised the first Labor Party branch of the Spanishspeaking community in Kensington, with 25 members..$^{45}$ However, the success of this incipient branch was limited, due to the lack of English-language skills of the branch members. This experience was instrumental for Languiller and others in realising the need to learn the basics in organising party political branches. The 1980s and the 1990s brought a new political reality to the Latin American community in Australia. One by one the dictatorships in Central and South America fell. The fresh air of democratic change removed the drive to continue with activities related to human rights and democratisation agendas.

However, Jeffrey Kennett's election victory as Liberal Premier of Victoria in October 1992 gave new impetus for members of the Latin American community to work for the union movement. Kennett held a clear anti-union agenda, which galvanised the community to fight against his policies. The Labor Party understood the need to unite a number of non-English speaking people for this task. The Greek MP, Nicky Dollis, former Labor member of the Victorian Parliament, influenced Languiller to become more active within the Party. Languiller had long been a supporter and member of the Uruguayan Communist Party and was reluctant to redirect his political interest from Uruguay to Australia. As a young student in Uruguay he had performed communication activities for the Movimiento de Liberación Nacional Uruguayo, known then as los Tupamaros. Languiller's involvement with los Tupamaros included a politically motivated shooting incident in which he received leg wounds, and several close encounters with the Uruguayan secret police. These incidents eventually persuaded Languiller of the need to leave the country. He escaped to Argentina, and from there he sought asylum with his family in Australia as a political refugee. The changed political landscape in Uruguay and the conservative policies of the Kennett Government were strong incentives for Languiller to refocus his attention on Australia. There was also support from other active political voices in Victoria to allow wider participation of migrants in the political system. According to Languiller there were members of political parties and religious leaders, who had been supportive of the solidarity agenda 
pursued by the Latin American community, who encouraged him and others to become politically active. Among them were Reverend Dick Wootton, Jean McLean, Brian Howe, Don Chipp, Cyril Primmer, Andrew Theophanous, Billy Davis and Alan Missen, all of whom supported the pro-democracy movements in Latin America in the 1970s.

The ascension of Languiller in 1999 as the first Uruguayan and first Latin American member of a parliament in Australia was the culmination of this process. In 2002 Languiller was promoted as Parliamentary Secretary for Community Services. In 2006 he retained the same position but also covered the portfolio of Multicultural Affairs, and one year later moved to the human services secretariat. Languiller has been an active spokesperson; he was the first parliamentarian to deliver speeches in the Mayan and Spanish Languages, ${ }^{46}$ and the first to cite Don Quixote de la Mancha in the Victorian legislative chamber. ${ }^{47}$

As with other ethnic groups, Latinos have been used for ghost political engagement. There have been cases of both Liberal and Labor parties stacking branches, whereby non-politically active members are signed up to swell branch numbers and to block-vote for a particular agenda. Melbourne newspaper The Age accused Languiller of branch stacking. However, he was exonerated after a parliamentary investigation, an internal Labor Party investigation, and a police and an Auditor General's report. Regardless of this, the electoral defeat of the Brumby Government in November 2010 removed Languiller's chance for promotion to a Ministry in the medium term. Like former Premier Brumby, Languiller moved to the back-bench. This defeat also deferred the Latin American community's short-term possibility of securing a representative in a position of senior leadership within the Australian political system.

\section{The Communist Party of Australia}

A relatively recent Latin American arrival to Australia in 1995 quickly climbed the ranks of the Communist Party of Australia. Wikipedia describes Vinicio Molina as:

a union official with the Construction, Forestry, Mining and Energy Union, WA branch. Mr Molina arrived in Australia in 1995 from his native Guatemala, Central America. A carpenter by trade, he worked as a trade unionist and a student activist in the 80s and 90s. He was elected as the Communist Party of Australia president at a meeting of the CPA

46 Victorian Parliament Speech, Hansard, 20 March 2003.

47 Victorian Parliament Speech, Hansard, 14 September 2005. 
Central Committee in February 2009. Mr Molina has worked tirelessly in solidarity with Latin America and he currently holds the position of president of the Australia-Cuba Friendship Society, ACFS WA branch. ${ }^{48}$

Although a number of solidarity groups remain in close contact, there is no evidence of any other Latin Americans being involved with the Communist Party of Australia.

\section{Political participation: The Latino community in the 21 st century}

Political participation of the Latin American community in Australia in the 21st century may be substantially different to that experienced by migrants in the 1970s and the 1980s. There is strong evidence that ethnic minorities have tended historically to align with the Labor Party. In her analysis of the Political Representation of Ethnic and Racial Minorities for the NSW Parliamentary Library Research Service, Karina Anthony expanded on this issue:

A brief examination of federal electorates reveals an apparent link between high proportions of NESB constituents, and electorates held by the ALP. After the 1998 federal election, only one of the top twenty ethnic electorates was not held by the ALP. Two-thirds of all ethnic electorates were held by that party (Zappalá: 2006). Federal electorates with high NESB populations are concentrated in Sydney and Melbourne. Of thirty-two electorates with more than 20 per cent of the population born in non-English speaking countries, sixteen are located in Sydney, fourteen in Melbourne and two in Perth. In 2001, 28 of these were held by the ALP and only four by the Liberals. According to Jupp this 'political domination' has 'lasted for many years and embraces some of the ALP's safest electorates, including those of five of the party's seven leaders over the past forty years' (Jupp: 2003). ${ }^{49}$

This also raises questions as to whether people migrating under different programs exhibit different voting patterns. The Latin American migration wave of the last two decades arrived under the skilled migration program, which tends to attract a different kind of migrant population than the earlier political refugees. In general terms, people under the skilled migration program

48 See: ‘Vinicio Molina', Wikipedia, http://en.wikipedia.org/wiki/Vinicio_Molina.

49 Anthony, op. cit., note 24. For Zappalá and Jupp (cited by Anthony), see: Gianni Zappalá, ‘The Political Representation of Ethnic Minorities: Moving Beyond the Mirror' in Marian Sawer and Gianni Zappalá (eds), Speaking for the People: Representation in Australian Politics, 2001, p. 156; James Jupp, How Well Does Australian Democracy Serve Immigrant Australians? Report No 1 for the Democratic Audit of Australia, Centre for Immigration and Multicultural Studies, The Australian National University, Canberra, 2003, n. 6, pp. 30-31. 
moving to Australia are seeking better economic opportunities. Given their different ideologies and motivations to emigrate in comparison with the pre1990s Latin American population, it is arguable that the new arrivals may tend to be more politically aligned to the Liberal rather than the Labor Party. Ada and Bernard Finifter found that 'new political learning is generally dependent upon previously established political attitudes. Nevertheless, migrants' political adaptation is also affected by the political context of the new residence' ${ }^{50}$ At best, the likelihood exists that a split now separates generations of Latin American migrants as followers of Liberal and Labor parties.

This snapshot of civic engagement reveals the variety of ways in which Latinos have been integrated into Australia society. While Latino migrants demonstrate above-average citizenship rates, they continue to display low levels of political participation nationally. To understand more fully the extent to which Latinos are integrated in Australian society we need to consider other indicators.

\section{Education participation: English-language skills}

A number of studies have concluded that immigrants fare worse in the labour market when their language skills are poor. Migrants tend to receive income below the earnings of comparable native-born workers. While researching the Spanish-speaking community in the USA in 2007, Chiswick and Miller explained that '[migrants' economic] disadvantages arise because of the lessthan-perfect international transferability of immigrants' human capital, their lack of knowledge of the institutions of the US labor market, and perhaps through discrimination' ${ }^{51}$ Language is seen as one of the most important factors in the process of integration.

According to census figures, language is no longer an integration barrier for Latino communities in Australia. At least 80 per cent of the Latino community speak English either very well or satisfactorily. In the case of Mexico, 70 per cent of the census respondents declared that they have a very good command of English. It is interesting to note that despite above-average employment and income rates, only 47 per cent of Uruguayans speak English very well; Colombians also have the same low percentage of English-language facility.

\footnotetext{
50 Ada W. Finifter, and Bernard M. Finifter, ‘Party Identification and Political Adaptation of American Migrants in Australia', Journal of Politics, Vol. 51 1989, (3), pp. 599-630.

51 Barry R. Chiswick, and Paul W. Miller, 'Modeling Immigrants' Language Skills', in B. R. Chiswick (ed.) Immigration (Research in Labor Economics), Volume 27, 2007, pp. 75-128.
} 







\section{Educational participation: Level of qualifications}

The OECD Report indicates that both the level of qualifications and the place where these qualifications were obtained are good indicators of integration. However, statistics relating to the Latino community in Australia cannot be compared to OECD figures because the contexts are substantially different. In most OECD countries migrants obtain their qualifications abroad. However, the first wave of Latinos has resided in Australia for more than 25 years, and during this time have either revalidated their qualifications or started anew. And having been drawn from the international student pool, the second wave of Latino migrants also have at least two years of studies in Australia as a minimum requirement to apply for residency. Australia has a strong share of the Latin American internationally mobile student market, which according to Calderón was:

[two] per cent in 2009 (compared to 1.5 per cent in 2001). For Australia, the total value of trade in educational services with Latin American countries totalled A $\$ 886$ million in 2010, compared with A $\$ 147$ million in 2001. The Latin American student market represents five per cent of Australia's educational services exports. ${ }^{52}$

The comparison here is between the Latino communities and the national average, although simply comparing the education processes between the first and second wave Latino immigrants offers useful results. The qualifications of the first wave were hard-won and occurred over many years. Except for Salvadorians, which are lower, in 2011 the postgraduate rates of these Latino communities were equal to or better than the Australian national postgraduate average of three per cent. The Mexican postgraduate rate was 18 per cent, more than four times the Australian national average, and Venezuelans - 13 per cent - and Colombians - 12 per cent - more than three times.

In 2011, 23 per cent of Australians held a Bachelors degree or above, but migrants from Venezuela, Colombia, Peru, Brazil and Mexico had more than twice this percentage: the new Latino settlers are more qualified in the tertiary education sector not only over their Latino counterparts but also in relation to the rest of Australia. This gives the new Latino migrant wave a distinct educational advantage and as a consequence the prospect of a much faster pace of integration.

52 Angel Calderón, Latin American Perspectives and Drivers for Tertiary Education Development: A PEST Analysis, The Observatory on Borderless Higher Education, London, September 2012. 










Turning now to other education and training qualifications, in 2011, 21 per cent of Australians in the age bracket 15-64 had Advanced Diploma, Diploma and Certificate-level qualifications. Comparisons here show that the older communities from Chile and El Salvador had 34 and 32 per cent-well above the national average. The new Latino communities of Brazil and Colombia had 18 per cent, three points below the national average. Mexico and Venezuela had percentages of technical education well below the Australian average, with 15 and 13 per cent respectively.

Table 7.11: Latin American people 15-64 years by country of birth and qualifications: Bachelors degree or above vs advanced diploma or below

\begin{tabular}{|l|l|}
\hline Country & $\begin{array}{l}\text { Bachelor } \\
\text { degree or } \\
\text { above }\end{array}$ \\
\hline Argentina & $24 \%$ \\
\hline Brazil & $48 \%$ \\
\hline Chile & $19 \%$ \\
\hline Colombia & $50 \%$ \\
\hline Ecuador & $22 \%$ \\
\hline El Salvador & $20 \%$ \\
\hline Mexico & $55 \%$ \\
\hline Uruguay & $11 \%$ \\
\hline Venezuela & $56 \%$ \\
\hline Peru & $34 \%$ \\
\hline Spain & $17 \%$ \\
\hline
\end{tabular}

\begin{tabular}{|l|l|}
\hline Country & $\begin{array}{l}\text { Advance diploma or } \\
\text { below }\end{array}$ \\
\hline Argentina & $29 \%$ \\
\hline Brazil & $18 \%$ \\
\hline Chile & $34 \%$ \\
\hline Colombia & $18 \%$ \\
\hline Ecuador & $29 \%$ \\
\hline El Salvador & $33 \%$ \\
\hline Mexico & $13 \%$ \\
\hline Uruguay & $31 \%$ \\
\hline Venezuela & $15 \%$ \\
\hline Peru & $29 \%$ \\
\hline Spain & $26 \%$ \\
\hline
\end{tabular}

Source: ABS Census 2011, ABS. Information extracted by the author using Table Builder Basic \& Pro, 8-21 May 2013.

Based on the above it is evident that both the old and new Latino communities are highly qualified, but in different sectors - the new communities in higher education and the most settled communities in the vocational education and technical training sector. So while both migration waves are well integrated based on educational outcomes, the newer ones were able to integrate much faster. 


\section{Economic participation: Labour force representation}

This indicator is defined by the International Labour Organisation (ILO) as:

a measure of the proportion of a country's working-age population that engages actively in the labour market, either by working or looking for work; it provides an indication of the relative size of the supply of labour available to engage in the production of goods and services.

The OECD Report found that 'In 2009-10, the average employment rate among immigrants across OECD countries was 64 per cent' ${ }^{53}$ The Australian workforce participation rate was 65 per cent in 2011 .

Older Latino communities tend to have lower participation rates than newer ones as their members have retired, are receiving medical treatment, or include long-term unemployed members who have ceased looking for employment.

All the Latino communities except Spaniards and Uruguayans have labour force participation equal to or higher than the OECD rate in 2009-10 and the Australian average rate in 2011. These two communities had very low labour force rates of 51 and 58 per cent respectively that cannot be accounted for on demographic grounds alone. Further study is required.

Table 7.12: Latin American people by labour force participation

\begin{tabular}{|l|l|}
\hline Country & Labour force participation rate \\
\hline Australia & $65.0 \%$ \\
\hline Argentina & $68.7 \%$ \\
\hline Brazil & $79.0 \%$ \\
\hline Chile & $65.0 \%$ \\
\hline Colombia & $79.8 \%$ \\
\hline Ecuador & $67.2 \%$ \\
\hline El Salvador & $71.2 \%$ \\
\hline Mexico & $73.9 \%$ \\
\hline Uruguay & $73.1 \%$ \\
\hline Venezuela & $79.8 \%$ \\
\hline Peru & $71.6 \%$ \\
\hline Spain & $51.1 \%$ \\
\hline
\end{tabular}

Source: ABS Census 2011, ABS. Information extracted by the author using Table Builder Basic \& Pro, 8-21 May 2013.

Of the new Latino communities, Colombia and Venezuela were at the top of the ladder in workforce participation with almost 80 per cent, followed closely

53 OECD, Settling In, op. cit., note 23, p. 90. 
by Brazil at 79 per cent. These percentages compared well with the national participation rate of 65 per cent and are consistent with the age profile of both communities. Generally the degree of workforce participation within the Latino community is consistent with the national average, thus displaying a strong level of integration.

\section{Economic participation: Unemployment rate}

Analysis of this indicator shows that there is some room for improvement in integration. The OECD Report states: 'On average, the immigrant unemployment rate is about 1.5 times higher than that of the native-born-about 12 per cent compared with 8 per cent in 2009-10. In all OECD countries, with the exception of Hungary, the unemployment rate among immigrants is higher than that among the native-born' ${ }^{54}$ To indicate the level of integration using this criterion a comparison is required between the national unemployment rate in Australia and the unemployment rate among Latino communities and that reported by the OECD. In 2011 the unemployment rate in Australia was 5.6 per cent, and many of the first wave of Latino immigrants are commensurate with this rate, although Uruguay has a lower level of five per cent.

The overall Latino unemployment rate average in 2011 of just over seven per cent compares well to the unemployment rate in the Latino population in 1987 of more than ten per cent. Youth unemployment at that time in some Latino communities exceeded 18 per cent. ${ }^{55}$

However, the new Latino settlers from Mexico, Brazil, Venezuela, Ecuador and Peru have higher unemployment rates. Mexicans in particular, despite a high level of qualifications - 55 per cent Bachelors degrees or above and 18 per cent postgraduates - have an unemployment rate of 9.7 per cent, 1.7 times higher than the national average. This percentage is also higher than the 1.5 times ratio reported by the OECD for the migrant population. Venezuela experienced an 8.7 per cent unemployment rate, 1.55 times higher than the Australian average. The remaining Latino communities had unemployment rates closer to the OECD benchmark. This is a clear sign that two of the new communities, Mexicans and Venezuelans, have problems adapting to the employment market.

\footnotetext{
54 OECD, Settling In, op. cit., note 23, p. 98.

55 Victor Del Río, Unemployment Amongst the Spanish-Speaking Youth, Victorian Ethnic Affairs Commission and the Spanish Latin American Welfare Centre (CELAS), Melbourne.
} 
Table 7.13: Latin America people in Australia: Unemployment rate

\begin{tabular}{|l|r|r|r|r|}
\hline Job status & Employed & Unemployed & \multicolumn{1}{l|}{ Total } & Unemployment rate \\
\hline Argentina & 7,406 & 440 & 7,846 & $5.6 \%$ \\
\hline Brazil & 9,994 & 790 & 10,784 & $7.3 \%$ \\
\hline Chile & 14,550 & 1,002 & 15,552 & $6.4 \%$ \\
\hline Colombia & 7,929 & 583 & 8,512 & $6.8 \%$ \\
\hline Ecuador & 1,029 & 79 & 1,108 & $7.1 \%$ \\
\hline El Salvador & 6,237 & 469 & 6,706 & $7.0 \%$ \\
\hline Mexico & 1,952 & 209 & 2,161 & $9.7 \%$ \\
\hline Peru & 5,333 & 454 & 5,787 & $7.8 \%$ \\
\hline Uruguay & 4,879 & 257 & 5,136 & $5.0 \%$ \\
\hline Venezuela & 2,215 & 210 & 2,425 & $8.7 \%$ \\
\hline Total Latinos & $\mathbf{6 1 , 5 2 4}$ & $\mathbf{4 , 4 9 3}$ & $\mathbf{6 6 , 0 1 7}$ & $\mathbf{7 . 2 \%}$ \\
\hline Spain & 5,861 & 358 & 6,219 & $5.8 \%$ \\
\hline Total & $\mathbf{6 7 , 3 8 5}$ & $\mathbf{4 , 8 5 1}$ & $\mathbf{7 2 , 2 3 6}$ & $\mathbf{7 . 0 \%}$ \\
\hline
\end{tabular}

Source: ABS Census 2011, ABS. Information extracted by the author using Table Builder Basic \& Pro, 8-21 May 2013.

\section{Economic participation: Income}

The OECD Report states that:

In all OECD countries for which data are available, immigrant household median income is lower than native-born income and, in half of the countries, it represents less than 80 per cent of the native-born median income. Aside from Austria, mixed household median income is comparable with that of native-born households and is even substantially higher in the case of Australia, Norway, Portugal, Switzerland, the United Kingdom and the United States. ${ }^{56}$

In Australia information on household income by country of birth was not available in the 2011 Census, so individual income has been used here. The census information points towards serious challenges in this integration indicator for the new Latino communities, both in obtaining employment or a source of income. The national average for people with 'nil income' was six per cent, but Mexico has 14 per cent, and Brazil and Venezuela at 12 per cent are still double the national average. However, once in the labour market, the highly qualified members of these communities ultimately tend to secure well-paid jobs. For

56 OECD, Settling In, op. cit., note 23, p. 55. 
instance, while the national average of people with weekly incomes of $\$ 2,000$ dollars and more was five per cent, the Venezuelan and Mexican communities in this category had ten per cent.

Table 7.14: Latin American people in Australia: Weekly income earners 2011

\begin{tabular}{|l|l|l|}
\hline Weekly earnings & Nil to $\mathbf{\$ 5 9 9}$ & $\mathbf{\$ 6 0 0}$ or more \\
\hline Australia & $51 \%$ & $41 \%$ \\
\hline Argentina & $46 \%$ & $36 \%$ \\
\hline Brazil & $42 \%$ & $32 \%$ \\
\hline Chile & $49 \%$ & $39 \%$ \\
\hline Colombia & $48 \%$ & $38 \%$ \\
\hline Ecuador & $48 \%$ & $38 \%$ \\
\hline El Salvador & $47 \%$ & $37 \%$ \\
\hline Mexico & $43 \%$ & $33 \%$ \\
\hline Peru & $46 \%$ & $36 \%$ \\
\hline Uruguay & $54 \%$ & $44 \%$ \\
\hline Venezuela & $40 \%$ & $30 \%$ \\
\hline Total Latinos & $46 \%$ & $36 \%$ \\
\hline Spain & $53 \%$ & $43 \%$ \\
\hline
\end{tabular}

Source: ABS Census 2011, ABS. Information extracted by the author using Table Builder Basic \& Pro, 8-21 May 2013.

The weekly income bracket occupied by the largest number of Australian income earners - nine per cent of the total - is the \$400 to \$499 range. Colombia had the highest representation in this bracket with 14 per cent, followed by Brazil at 13 per cent. The Spanish and the Uruguayan communities were consistent with the national figure. 
7. Latinos in Australia



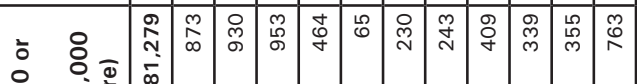

这。草





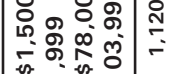

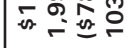

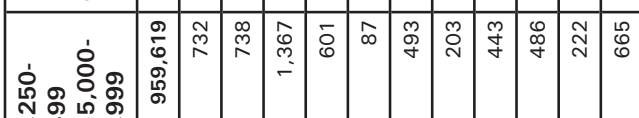
-

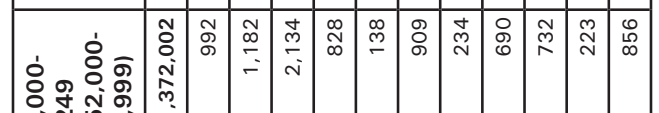

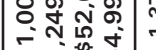



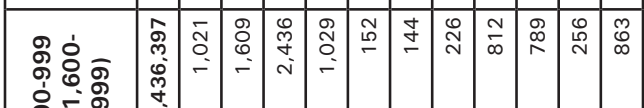

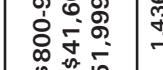

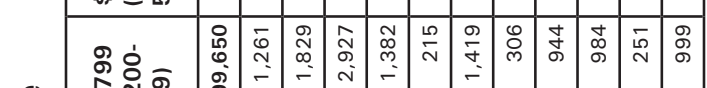

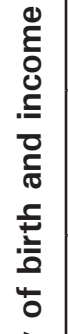

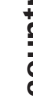

ำ

$\frac{8}{2}$

을

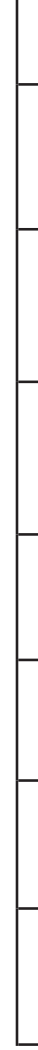

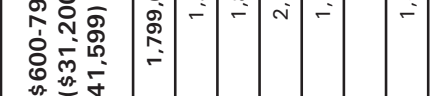

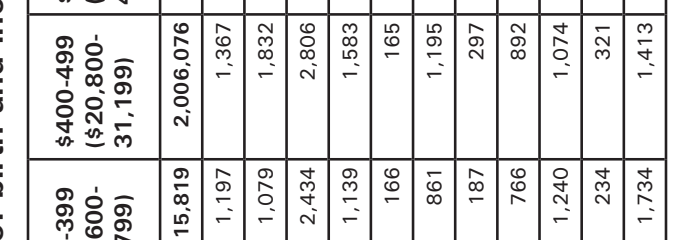
西





유요



זٓ

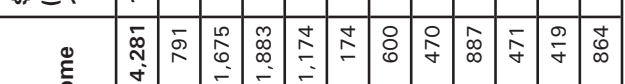

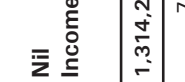

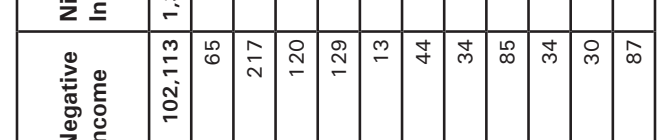

2.-

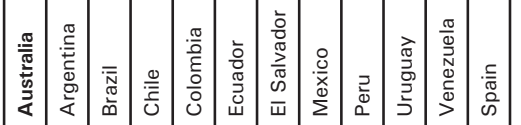



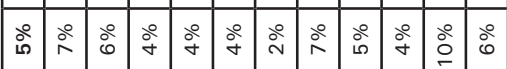

ஸे ๐े

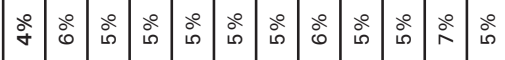

○

ஃ̊

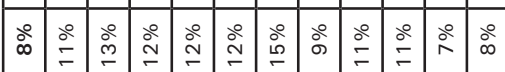



ळ $\cong$ ○े

œ

○े ๖े

@

○े $\cong$ 을

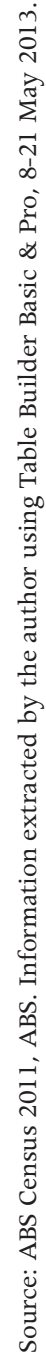




\section{Economic participation: Employment/qualifications}

It is generally assumed that employment is strongly correlated to the level of qualifications. If this is the case, the new Latino communities have a clear advantage over the old ones. But in relation to employment status other variables (such as length of settlement), may be as or more important than the level of qualifications. We conducted an income/qualifications cross tabulation analysis to test this assumption.

In Australia only four per cent of people with postgraduate degrees were unemployed in 2011. Two of the old Latino communities with postgraduate qualifications were just below this unemployment rate: Argentina, at three per cent, and El Salvador-2.2 per cent. El Salvador's rate is surprising as it is a group which tends to have low numbers of postgraduate qualifications, low weekly earnings and high levels of unemployment. However, it appears that the few Salvadorians at the top of the qualification ladder have managed to insert themselves successfully into the Australian employment sector. Ecuador displayed the highest employment rate among its postgraduate members. However, this figure has to be taken with caution because the absolute number of postgraduate Ecuadorians is very low, at 75 .

Venezuelans also have an employment challenge among their most qualified compatriots, with an unemployment rate of more than nine per cent. The postgraduate members of the Chilean community have adapted healthily to the employment market. People from El Salvador and Argentina, with postgraduate qualifications, are inserted into the job market on a better footing than those born in Australia. 


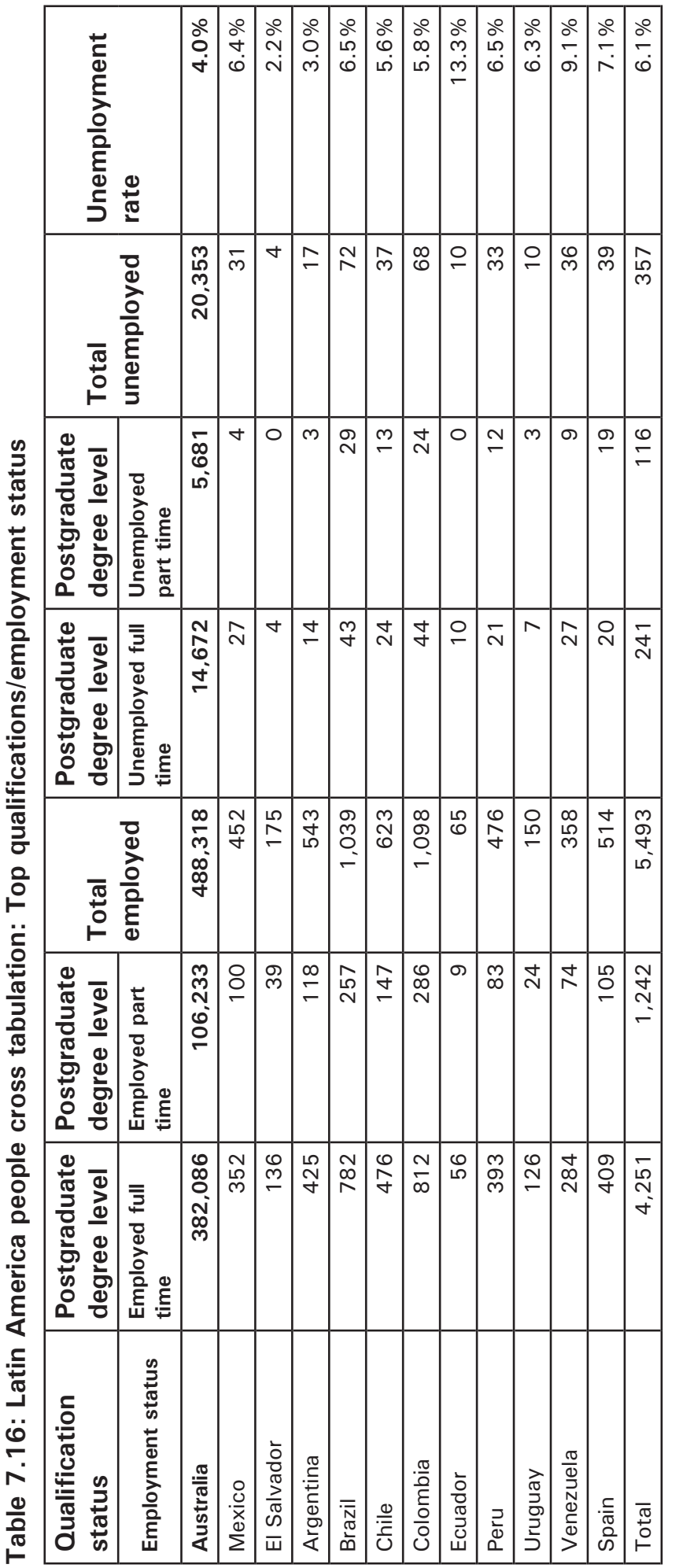

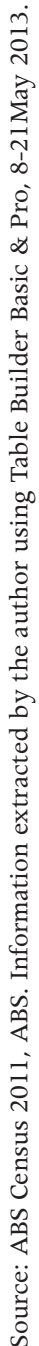




\section{Economic participation: Employment by industry}

The 2011 Census paints a clear picture of the industries in which most Latinos are employed. It seems that each community targets specific industries. For instance, Mexicans and Venezuelans are over-represented in the professional, scientific and technical services industries, with 16 per cent each, in relation to a national average of seven per cent.

At 14 per cent of people working in the manufacturing sector, Chileans have a much higher percentage than the national average of nine per cent. Brazil is high in the accommodation and food services industry with 16 per cent, more than double the national average of seven per cent. Mexico and Colombia with 13 per cent are also considerably higher than the national average for the hospitality industry.

Fully 21 per cent of people from El Salvador work in the health care and social assistance industries, which is nine per cent more than the national 12 per cent average. The Chilean and Peruvian communities also both register a high proportion of their workforce in these industries - 17 per cent.

On the other hand, there are industries in which Latino workforce participation is minimal in relation to the rest of the Australian population. Among these are agriculture, forestry and fishing; mining; electricity, gas, water and waste services, as well as information media and telecommunications, rental, hiring and real estate services, arts and recreation services. 
7. Latinos in Australia

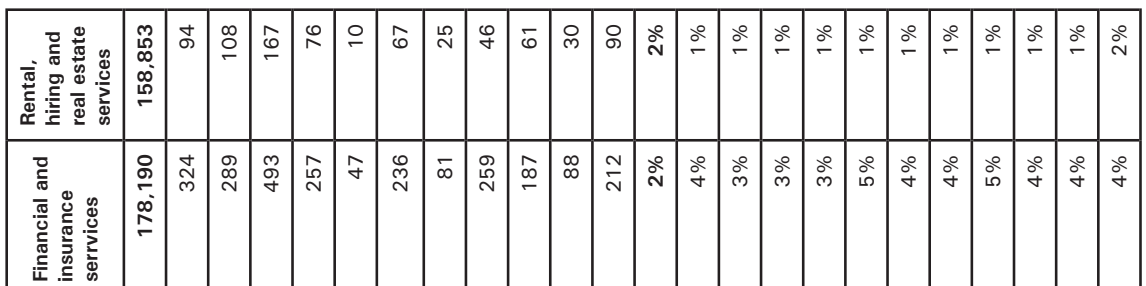

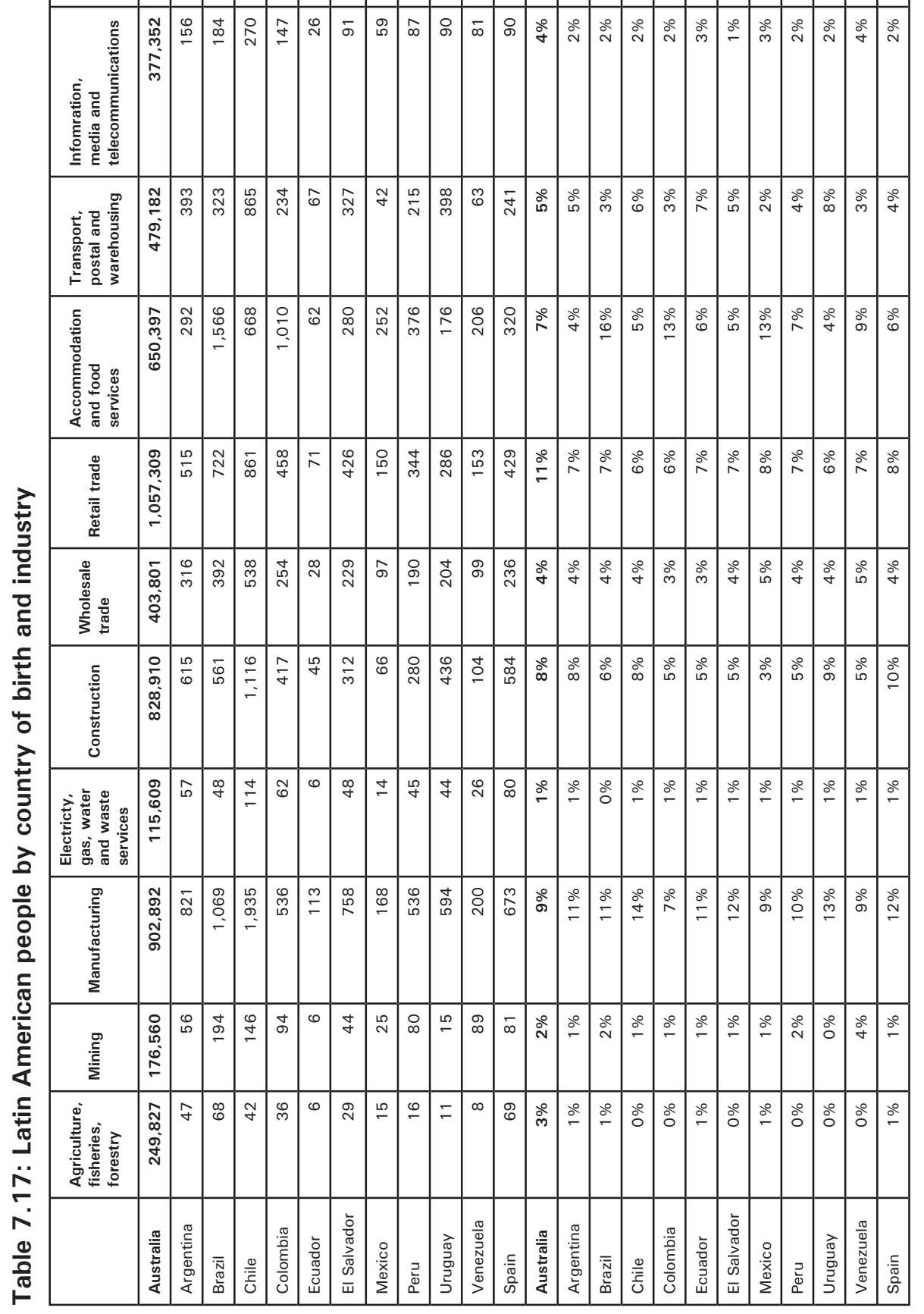

|⿰讠 


\section{Economic participation: Employment by occupation}

As stated earlier, the Latino communities tend to concentrate in specific occupational areas. Venezuela and Mexico are more represented in the professional category and they have 38 and 36 per cent respectively in relation to the national average in this occupation category of 22 per cent. Chile is also well represented with 17 per cent in the technicians and trade workers category in relation to the 14 per cent rate nationwide. Sixteen per cent of Brazilians worked in community and personal services, as compared with ten per cent in the overall Australian population.

Uruguayans, with ten per cent, have a strong presence as machine operators and drivers, compared to seven per cent nationwide. Colombians have a substantial presence as labourers, with 25 per cent compared to nine per cent in the rest of the country's working population. Conversely, people from El Salvador, with six per cent, are under-represented as managers compared to 13 per cent Australiawide. Mexico and Venezuela are also under-represented in the technicians and trades workers category, with eight per cent compared to 14 per cent for the rest of Australia.

This data again indicates that settlement groups tend to prefer specific occupations, possibly as a result of their networks, and again indicating a strong ability to integrate. 


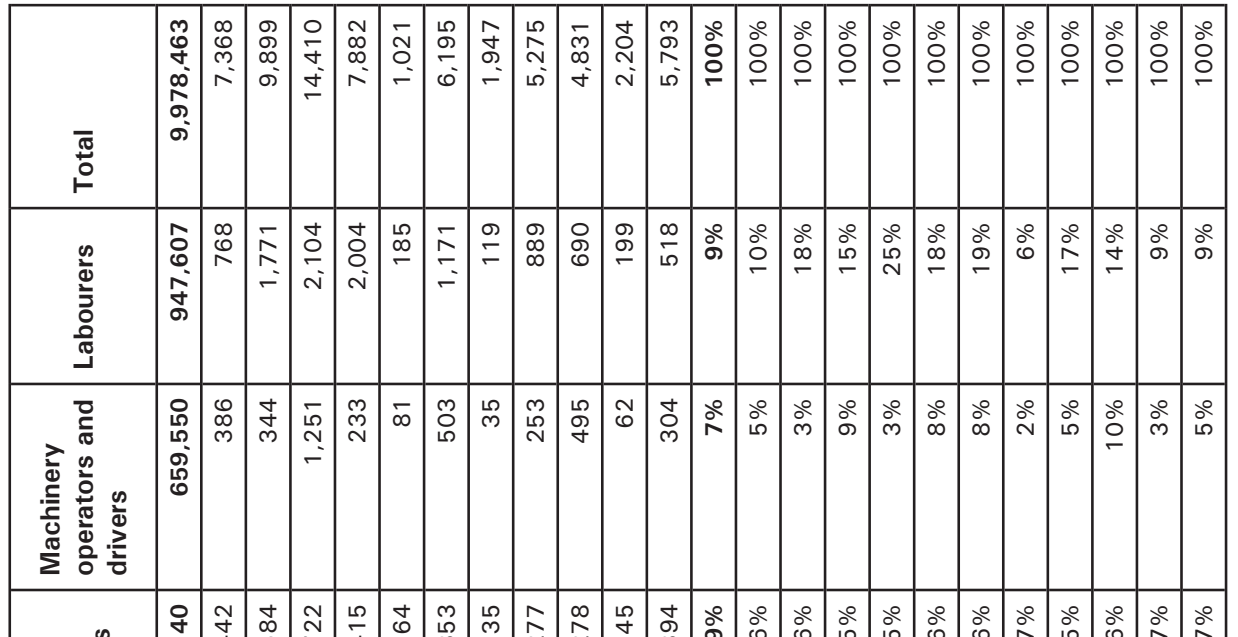

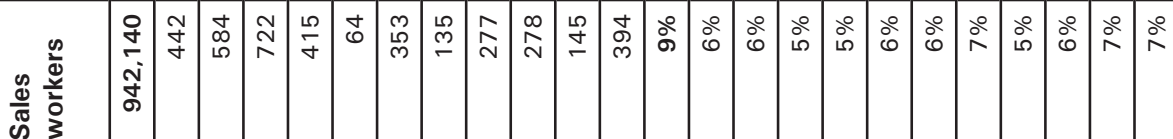

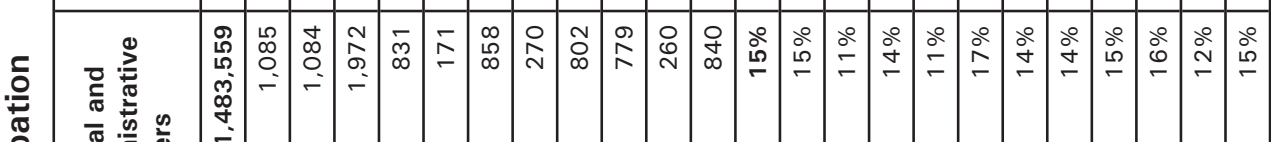

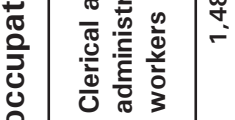

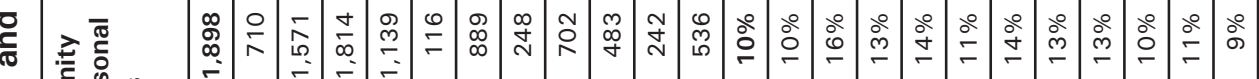
空

4

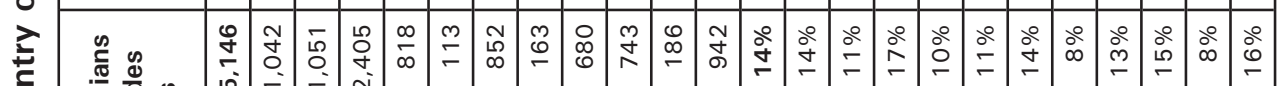

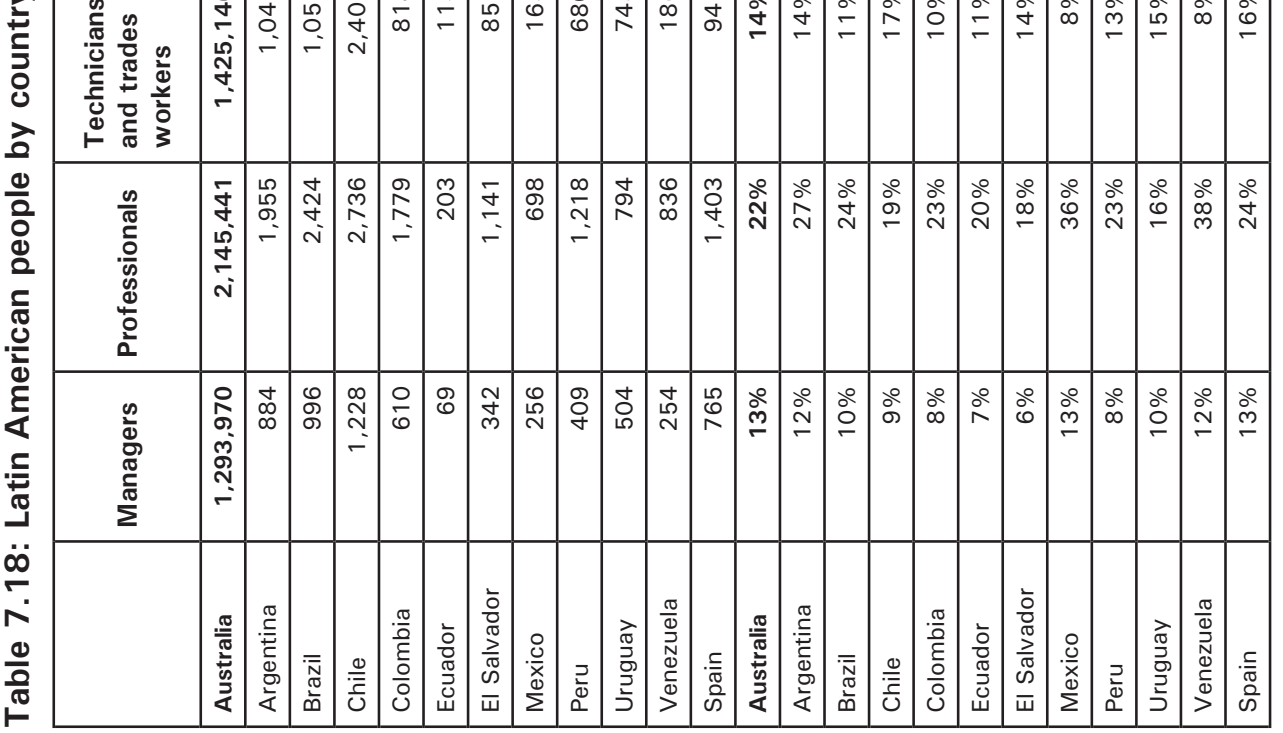




\section{Social participation: Need for assistance}

The OECD does not regard the need for assistance as an indicator of social participation and therefore a factor towards integration. However, it can be argued that the 'need for assistance' imposes a great burden on society generally. The affected members would tend to focus on solving their individual problems rather than focusing outwards.

The 2011 Census offers a useful snapshot of the communities' need for assistance. Included in this category are older people, and people with disabilities or who are disabled for health reasons. In Australia, five per cent of the population comprised this category in 2011. Spain had the highest rate with ten per cent, which is double the national average, closely followed by Uruguay, with eight per cent. The new Latino communities of Mexico, Brazil, Colombia and Venezuela had the lowest need for assistance with a rate of just one per cent.

Table 7.19: Latin American people by country of birth and needs for assistance

\begin{tabular}{|c|c|c|c|c|c|c|}
\hline & $\begin{array}{l}\text { Has need for } \\
\text { assistance }\end{array}$ & $\%$ & $\begin{array}{l}\text { Does not } \\
\text { have need for } \\
\text { assistance }\end{array}$ & $\%$ & Not stated & Total \\
\hline Australia & 998,602 & 5 & $19,287,677$ & 90 & $1,221,440$ & $21,507,719$ \\
\hline Argentina & 577 & 5 & 11,252 & 94 & 158 & 11,987 \\
\hline Brazil & 162 & 1 & 14,153 & 98 & 194 & 14,509 \\
\hline Chile & 1,349 & 5 & 23,219 & 93 & 370 & 24,938 \\
\hline Colombia & 158 & 1 & 11,002 & 97 & 158 & 11,318 \\
\hline Ecuador & 78 & 4 & 1,635 & 94 & 27 & 1,740 \\
\hline El Salvador & 495 & 5 & 9,022 & 93 & 134 & 9,651 \\
\hline Mexico & 41 & 1 & 3,170 & 97 & 46 & 3,257 \\
\hline Peru & 277 & 3 & 8,044 & 95 & 120 & 8,441 \\
\hline Uruguay & 778 & 8 & 8,296 & 90 & 163 & 9,237 \\
\hline Venezuela & 33 & 1 & 3,343 & 98 & 29 & 3,405 \\
\hline Total Latinos & 3,948 & 4 & 93,136 & 95 & 1,399 & 98,483 \\
\hline Spain & 1,247 & 10 & 11,563 & 89 & 245 & 13,055 \\
\hline Total & 9,143 & 4 & 197,835 & 94 & 3,043 & 210,021 \\
\hline
\end{tabular}

Source: ABS Census 2011, ABS. Information extracted by the author using Table Builder Basic \& Pro, 8-21 May 2013.

This data is consistent with the argument that the new Latino communities have fewer barriers to integration, as their need for assistance is minimal-one per cent or less - in comparison to the national average of five per cent. 


\section{Conclusion}

Analysis of relevant data reveals that Latin American communities have settled successfully in Australia compared to other OECD countries; and compared to other ethnic immigrant groups and the national Australian average.

For the more established arrivals in the Latino community, the changed political and economic circumstances in their respective countries of origin encouraged them to refocus their attention on Australia. As a result some of them have participated more actively in the political, economic and academic life of their new country. Their members shifted their position, from being outward-looking communities in the 1970s and 1980s, to becoming inward-looking from the mid1990s onwards.

For the new Latino communities the process of settlement in Australia has been faster than that of the earlier wave, largely because they possess a sound command of English and strong qualifications on arrival, which they have expanded with local education.

Most of the indicators analysed describe a Latino community that is comfortable with itself and which has achieved a high level of integration (see Table 7.22). Out of 12 integration indicators, the Latino community rated high in five, medium in four, low in two and very low in one, namely political participation. For both the old and the new Latino migrants, integration into the economic and educational sectors of Australia is on the right track.

A sense of permanency: The old and new Latino migrants have a clear purpose and the relevant skills to settle in Australia permanently. Factors that inhibited integration in the past have been left behind, including nationalism, detachment from the new country, lack of English proficiency, low levels of education, transplantation from rural to urban regions, and full and exclusive political commitment to their own countries of origin.

A high level of language skills and qualifications acquired locally: The old and new Latino settlers have high levels of vocational and educational qualifications, most of which were acquired in Australian tertiary institutions or vocational education and training institutes; hence, their contribution to Australia has been substantial and immediate.

In the ladder of the integration process, political participation and policymaking participation are at the top. In these areas Uruguayans have excelled, but other Latino communities are lagging behind. The Latino community needs more political representatives, and increased involvement in political parties and non-governmental organisations. 


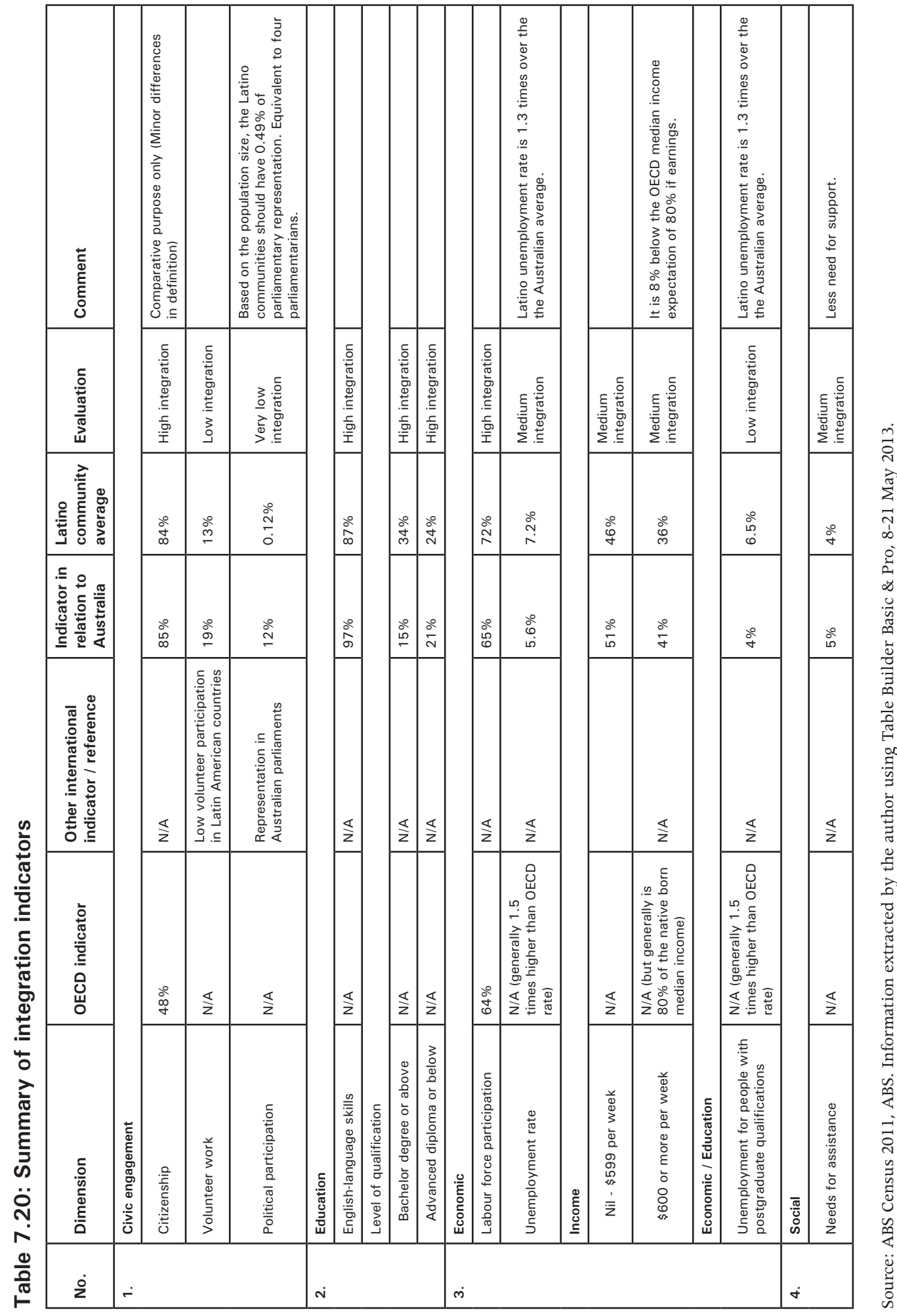


The lack of networks and targeted employment programs by government or business initiatives may also be a factor slowing the speed with which new waves of Latinos are joining the labour market.

The section below identifies a number of opportunities that would reduce the political and economic integration gaps in the quest to hasten the integration process, so that Latino communities can fully contribute their skills and experience to help build a stronger Australia.

\section{Opportunities}

There is a clear opportunity to increase engagement in political, economic and academic matters, policy implementation and institutional and capacity building, in order to reposition and integrate Latinos into Australian society in areas such as:

Developing strategic partnerships between Australia and the Latino community: There is a wealth of experience and human and intellectual capital among the Latino communities. This wealth of knowledge and experience could be used by government and the private sector in Australia to enhance the economic and social relationships with the wider Spanish-speaking world.

Policy-making: The Latino communities can play a vital role in the formulation and implementation of policies and the development of strategic papers aimed at improving the political, economic and educational relationships with Latin America. For instance, Uruguayan-born Telmo Languiller and Argentine-born Alexis Esposto were two of the main drivers behind the strategy paper 'Latin America in Victoria: a vision for growing trade, investment and cultural links', launched in October $2010 .^{57}$ More can be done.

Institutional and capacity building: In Australia we have a number of institutions which are actively engaged with Latin America, for example the Council on Australia Latin America Relations (COALAR), and Austrade. There is a clear opportunity to strengthen these organisations by:

1. including representatives of the Latino communities;

2. replicating these organisations at state level, in particular in those states where most of the Latino communities are located (NSW, Victoria and Queensland);

3. linking representatives of the Latino communities with academic and research institutions.

57 Minister for Industry and Trade, 'Victoria to tap into Latin American Opportunities', Australia-Latin America Business Council (ALABC), 1 November 2010. 
Institutional services delivery: There are opportunities to increase the participation of the Latino community in the delivery of key services. For example, during the Royal Melbourne Institute of Technology (RMIT) First Ibero-American Network Event held on 9 May 2013, Roger Frankel, the Honorary Consul of Brazil in Victoria - and former Australian Ambassador to Venezuela, Colombia, Ecuador and the Dominican Republic - suggested scrapping the English-language skills requirement for receiving an Australian student visa. This novel idea could provide new impetus to the educational sector by increasing demand for the provision of English-language courses and the delivery of training in languages other than English in Australia. It could also promote the learning of second languages in the country. The Latino communities could play a strategic role in such an educational enterprise.

The strategic need to speed our mutual understanding: The speed of settlement of Latinos into Australia can also be assisted by increasing the knowledge and understanding of Latin Americans about Australia, and of Australians about Latin America. For instance, Australia has strategic interest in its relationship with the United States. The influence of the Spanish-speaking communities in that country is growing rapidly, and may have an impact on future government priorities. Australia has the opportunity to develop its understanding of the Latin American people by looking at the aspirations and motivations of the Latino communities in Australia: it is a local window of opportunity.

There are other things that could improve this understanding. Even now, in the 21 st century, Latin American-born immigrants have to fill an out-dated immigration form that geographically defines South America as any country south of the US border - although this error is understood by the immigration authorities, they are reluctant to correct it for economic and statistical reasons. The Australian Bureau of Statistics (ABS) classifies Mexico as part of Central America instead of North America. There is also a measure of diplomatic insensitivity: for instance, the ABS identifies the controversial islands off the coast of Argentina as the 'Falklands Islands' instead of 'Las Malvinas'. Given that the UN considers the sovereignty of the islands an unresolved issue and demands dialogue between the UK and Argentina to resolve this dispute, Australia should take the diplomatic stance of referring to these islands as the Falklands/Malvinas Islands.

Promoting the teaching of the Spanish and Portuguese languages:Teaching of these languages would encourage mutual understanding, and increase economic and educational exchanges. The Latino community is qualified to support this endeavour. 
Development of local networks: As the above analysis shows, the key to making sure there is faster integration into Australian society is to develop networks and increase the understanding of Latin America by Australian-born people. For instance:

Business networks: by establishing Australia-Latino networks through national and country-specific Chambers of Commerce such as the Australian Latin American Business Council (ALABC) and the Mexican-Australian Chamber of Commerce. These chambers allow cross-fertilisation between Australian-born and Latino people. For instance, the current President of the Mexican-Australian Chamber of Commerce is Victor Perton, a former Australian parliamentarian and Victorian Commissioner to the Americas. A person like Victor brings a wealth of knowledge and strong local networks to the Mexican business world in Australia.

Academic networks: It is paramount to support research networks such as the Association of Iberian and Latin American Studies of Australasia (AILASA), the Institute of Latin American Studies (ILAS) at La Trobe University, the Australian National Centre for Latin American Studies (ANCLAS) at The Australian National University, the Sydney University Research Community for Latin America (SURCLA), and the recently formed Ibero-American Network at the Royal Melbourne Institute of Technology (RMIT), among others.

Promoting regional and country to country workshops, such as the University of Melbourne's Australia-Latin American Dialogue that took place in August 2012 and the Bi-National Workshop Australia-Argentina that took place from 8-10 May 2013 in Bahia Blanca and brought together Australian representatives from the universities of New England, Melbourne, La Trobe, Swinburne, Sydney, and the CSIRO, and Argentinean universities such as Quilmes, Nacional del Sur and Bahia Blanca.

Women's Networks, such as the Colectivo Mujer in Sydney, a group of Latinas who strongly identify with Latin American cultures as well as contribute to feminism in their community and Australia generally.

Researcher to researcher networks: Researchers in Australia have developed their own field-specific networks. It is important to learn about these enterprises and, whenever possible, build upon them. A good example is the Chilean-born Professor Rodrigo Marino (Melbourne University) and the Argentine-born Alex Esposto, who are building strong research networks between the University of Melbourne, Swinburne Institute of Technology and Chilean and Argentinean educational institutions. 
Student networks: One of the strongest student networks in Australia is the one developed by Zoe Dauth at Melbourne University. It offers an effective model for future inter-university student networks. Students' participation in university affairs is a recognised stepping-stone in the path towards political participation.

Social media networks: Linkedin and Facebook and specific interest blogs could assist to connect both the early and new Latino settlers in order to further their chances of gaining employment. This is already occurring in the case of Mexbourne, a Yahoo group created by Mexican IT Engineer Pedro Chan; and by MexVic, the Mexican community association in Victoria.

These networks alert their members to new employment opportunities. Even informal groupings, such as the one I belong to-'El Sindicato': formed by people from seven different nationalities and who have met every week for the last 25 years - can provide invaluable support for research activities.

Developing professional profiles: Many migrants have occupied high professional and executive positions in their own countries of origin. It would be in the interest of the wider Australian community to collect information concerning the working experience gained by Latinos while living in their own countries of origin. This information will help identify more precise ways to capitalise on this expertise from a policy-making and implementation perspective.

Establishing links with employment organisations: On the one hand, there is a clear need in Australia for highly qualified people, as demonstrated by the 83,840 people working with temporary 457 visas as at 31 December 2012. None of the top 15 countries sourcing the 457 Visa are from Latin American countries. Out of the 33,720 holders of 457 visas in 2011-12, 83 per cent were classified as having Skill 1 and 2 levels. Interestingly enough, the skill levels required by Australian employers match those from the Latino community. There is an opportunity to explore further the extent to which some of the 1,636 unemployed Latinos with skill level 1 - post-graduate qualifications and Bachelors degrees - could fill part of this employment gap, thereby reducing the number of workers having to be sourced from elsewhere.

Self employment: It would be desirable to have assistance programs linking new migrants in general, and the Latino community in particular, to micro-financing and self-employment opportunities. The profile of the new Latino communities indicates a strong inclination to start self-employment businesses. Therefore, there is an opportunity to create information channels to facilitate the creation of businesses and access to capital. For example, there are successful stories of microfinance programs initiated by NAB and Westpac, which are targeting this new wave of business immigrants. The government could improve access 
to world's best practice self-employment programs such as the New Enterprise Incentive Scheme (NEIS), which assists unemployed people. It is pertinent to note that the current President of NEIS is Ariel Moses, who was born in Chile.

Mentoring economic and political participation: The old Latino communities could play a mentoring role for the new ones. The oldest settlers, represented by Uruguay and Spain, have already adjusted. Uruguay, in particular, can be singled out as the Latino community which has integrated most fully. The unemployment rate of members of this community is lower than their Latino counterparts and that of the rest of the country, and they earn the highest weekly income average. It also has strong political engagement.

Although members of the new communities also hold the advantage of being better qualified to fill highly skilled jobs, they lack cultural and political skills to participate actively in the Australian political system; in this regard there would be value in connecting the established Latino community with emerging immigrant groups.

English proficiency: The new and younger Latino communities represented by Brazil, Colombia, Venezuela, Peru and Mexico with high levels of English proficiency could become 'language and cultural' ambassadors between Australian and Latin American businesses and, one day, expand the offer of educational services in Australia by providing courses in the Spanish and Portuguese languages.

These communities are growing most quickly, and at current trends will be paramount on the Latino population ladder, sooner rather than later.

\section{Conclusion}

This analysis provides the evidence to affirm that both the first- and secondwave Latino communities are generally well integrated into Australian society but still have more to offer. They each have advantages and disadvantages that can be worked with to build stronger communities, which contribute more fully to the wider Australian society. The first-wave communities are savvy, with strong networks, and the second-wave communities are smart, with strong qualifications. Working together and with the right government policies these groups can help to develop a stronger Australia internally, but also to develop stronger external ties with the growing economic powerhouses of the Latin American region. 
This is a side of the multicultural agenda that has not been fully explored. All the pieces of the puzzle are now on the table: it is time to bring them together so that Latinos can contribute to Australia's bigger picture.

\section{References}

ABC Radio National, 'Tortured Questions', Background Briefing, 26 May 1996, http://www.abc.net.au/rn/.

backgroundbriefing/stories/1996/10766.htm, accessed 14 October 2011.

Age, 'Priest at home with Melbourne's migrants', The Age, Obituaries, 13 January, 2005, First Edition, Business Section Page 7. [no locatable reference].

Anthony, Karina, 'The Political Representation of Ethnic and Racial Minorities', Briefing Paper 3/06, NSW Parliamentary Library Research Service, 2006.

Argus, 'Classified Advertising', Melbourne, Victoria: 1848-1956, 21 August 1916, p. 1, http://nla.gov.au/nla.news-article1591391, accessed 27 September 2011.

Baldovino, Carlos, interview, 9 December 2010.

Bernie Banton Foundation, http://www.berniebanton.com.au/, accessed 2 November 2013.

Calderón, Angel, 'Latin America tertiary education as an emerging systemAustralia's future market', paper delivered at Melbourne-Latin America Dialogue, The University of Melbourne, August 2012.

, Latin American Perspectives and Drivers for Tertiary Education Development: A PEST Analysis, The Observatory on Borderless Higher Education, London, 2012.

Charities Aid Foundation (CAF), World Giving Index 2011: A Global View of Giving Trends, https://www.cafonline.org/pdf/world_giving_index_2011_191211. pdf, accessed 2 November 2013.

Chiswick, Barry R., and Paul W. Miller, 'Modeling Immigrants' Language Skills', in Barry R. Chiswick (ed.) Immigration (Research in Labor Economics), Volume 27, 2007, pp. 75-128. DOI: 10.1016/S0147-9121(07)00003-9.

Del Río, Victor, Unemployment Amongst the Spanish-Speaking Youth, Victorian Ethnic Affairs Commission and the Spanish Latin American Welfare Centre (CELAS), Melbourne, 1987. 
Department of Immigration and Citizenship (Economic Analysis Unit, Chief Economist), 'Population flows Immigration aspects 2009-2010 edition', Australian Government, Canberra, 2010.

Department of Immigration and Citizenship, National Agenda for a Multicultural Australia, http://www.immi.gov.au/media/publications/multicultural/agenda/ agenda89/issues.html. [This is not accessible online.]

Department of Immigration and Citizenship, Settlement Outcomes of New Arrivals: Report of Findings, Policy Innovation, Research and Evaluation Unit, Department of Immigration and Citizenship, April 2011, http://www. immi.gov.au/media/publications/research/_pdf/settlement-outcomes-newarrivals.pdf, accessed 2 November 2013.

Department of Immigration and Ethnic Affairs, 'Review '81, Canberra', Parliament of Australia, Parliament Library, 1981, accessed 16 June 2010.

1982, 'Review '82, Canberra', 16 June 2010.

- 'Review '83, Canberra', Parliament of Australia, Parliament Library, 1983, accessed 16 June 2010.

- ' 'Review '85, Canberra', Parliament of Australia, Parliament Library, 1985, accessed 16 June 2010.

Finifter, Ada W., and Bernard M., Finifter, 'Party Identification and Political Adaptation of American Migrants in Australia', Journal of Politics, Vol. 51, 1989, (3), pp. 599-630.

Jupp, James (ed.), The Australian People: An Encyclopedia of the Nation, Its People and Their Origins, Cambridge University Press, 2nd edn, Cambridge, 2001.

, How Well Does Australian Democracy Serve Immigrant Australians? Report No 1 for the Democratic Audit of Australia, Centre for Immigration and Multicultural Studies, The Australian National University, Canberra, 2003.

Languiller, Telmo, interview, 25 April 2010.

López, Rafaela, interview, 14 May 2010.

López, Rafaela, Orígenes. Influencia y contribución de origen español y latino Americano en Victoria, 1901-2001 (The presence and contribution of Victorians of Spanish and Latin American origins, 1901-2001). Australia: CELAS, The Spanish Latin American Welfare Centre, 2002. ISBN: 0-9579773-0-1. 
Migrant Workers' Centres in multiculturalism, 18 February 2009. Source: not available. Format: mov (Quicktime); File size: 14.9 MB. Length: 05min 43sec. [Not locatable with this reference.]

Minister for Immigration and Multicultural Affairs, Media Release, MPS27/96, 3 July 1996, http://www.aph.gov.au/library/pubs/online/refugees, accessed 16 October 2011.

Minister for Immigration and Multicultural Affairs, Media Release, MPS70/96, 30 October 1996, http://www.aph.gov.au/library/pubs/online/refugees, accessed 16 October 2011.

Minister for Immigration, Local Government and Ethnic Affairs, Media Release, MPS 41/92, 24 July 1992, http://www.aph.gov.au/library/pubs/online/ refugees, accessed 16 October 2011.

Minister for Industry and Trade, 'Victoria to tap into Latin American Opportunities', Australia-Latin America Business Council (ALABC), 1 November 2010, http://www.alabc.com.au/News/tabid/1965/ID/516/ Victoria-to-tap-into-Latin-American-Opportunities.aspx, accessed 2 November 2013.

Nationality Act, ('New Law published in the Official Journal of the Federation on January 23, 1998'), Ley de Nacionalidad Cámara de Diputados del H. Congreso de la Unión, Secretaría General, Secretaría de Servicios Parlamentarios, Dirección General de Bibliotecas, 20 March 1998. http:// www.yucatan.gob.mx/gobierno/orden_juridico/Federal/Leyes/nr215rfl. pdf, accessed 2 November 2013.

New South Wales Election Results 1856-2007 (as at 5 July 2007), 'NSW Elections: Camden - 1999', http://www.parliament.nsw.gov.au/resources/ nswelectionsanalysis/1999/Camden.htm, accessed 2 November 2013.

New South Wales Election Results 1856-2007 (as at 5 July 2007), 'NSW Elections: Smithfield - 2003', http://www.parliament.nsw.gov.au/resources/ nswelectionsanalysis/2003/Smithfield.htm, accessed 2 November 2013.

OECD (Organisation for Economic Co-operation and Development), Settling In: OECD Indicators of Immigrant Integration 2012 Report, OECD Publishing. http://dx.doi.org/10.1787/9789264171534-en, accessed 2 November 2013.

Piperno, Cesar, interview, 16 June 2010.

Sydney Herald, (NSW: 1831-1842) Article, 'Legislative Council', Friday 6 July 1838, pp. 2-3, Trove: digitised newspapers and more, http://trove.nla.gov.au/ newspaper/... ["Fryre"], accessed 15 October 2011. 
Sydney Herald, (NSW: 1831-1842) Article, 'Shipping Intelligence. Arrival', 3 July 1837, p. 2, Trove: digitised newspapers and more, http://trove.nla.gov.au/ ndp/del/article... [“Fryre"], accessed 15 October 2011.

UNHCR (United Nations High Commissioner for Refugees), The State of the World's Refugees, 1997-1998, Oxford University Press, 1997, accessed 16 June 2003 Parliament of Australia, Parliament Library.

Victorian Electoral Commission, 'State Election 1999: Eumemmerring Province', https://www.vec.vic.gov.au/.

Results/state1999resultEumemmerringProvince.html, accessed 2 November 2013.

Victorian Parliament Speech, Hansard, 20 March 2003.

Victorian Parliament Speech, Hansard, 14 September 2005.

Victorian Trades Hall Council. Archives at the University of Melbourne, 101/27, 1976-91, 13 Arki Boxes www.lib.unimelb.edu.au/collections/archives/ collections/, accessed 2 November 2013.

'Vinicio Molina', Wikipedia, http://en.wikipedia.org/wiki/Vinicio_Molina, accessed 2 November 2013.

York, Barry, 'Australia and Refugees, 1901-2002: An Annotated Chronology Based on Official Sources', Social Policy Group, Department of Immigration and Ethnic Affairs, Review 1990, Canberra, 1990, accessed 16 June 2003, Parliament of Australia, Parliament Library.

Zappalá, Gianni, 'The Political Representation of Ethnic Minorities: Moving Beyond the Mirror', in Marian Sawer and Gianni Zappalá (eds), Speaking for the People: Representation in Australian Politics, Melbourne University Press, 2001. 
This text taken from Australia and Latin America: Challenges and Opportunities in the New Millennium, Edited by Barry Carr \& John Minns, published 2014 by ANU Press, The Australian National University, Canberra, Australia. 